\title{
High-Level Waste Melter Alternatives Assessment Report
}

R. B. Calmus

Date Published

February 1995

Prepared for the U.S. Department of Energy Office of Environmental Restoration and Waste Management

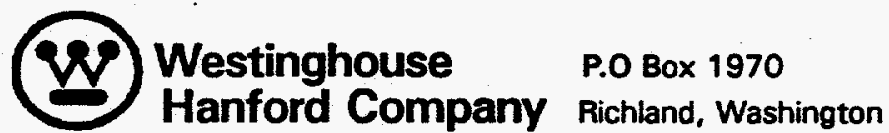

Hanford Operations and Engineering Contractor for the U.S. Department of Energy under Contract DE-ACO6-87RL10930 


\section{RELEASE AUTHORIZATION}

Document Number: WHC-EP-0847

Document Title: High-Level Waste Melter Alternatives Assessment

Report

Release Date: $\quad 02 / 08 / 95$

This document was reviewed following the procedures described in WHC-CM-3-4 and is:

APPROVED FOR PUBLIC RELEASE

WHC Information Release Administration Specialist:
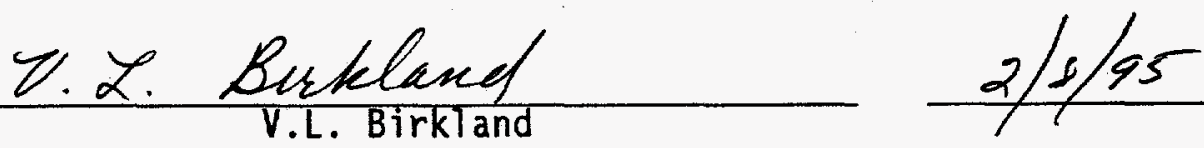


\section{DISCLAIMER}

This report was prepared as an account of work sponsored by an agency of the United States Government. Neither the United States Government nor any agency thereof, nor any of their employees, make any warranty, express or implied, or assumes any legal liability or responsibility for the accuracy, completeness, or usefulness of any information, apparatus, product, or process disclosed, or represents that its use would not infringe privately owned rights. Reference herein to any specific commercial product, process, or service by trade name, trademark, manufacturer, or otherwise does not necessarily constitute or imply its endorsement, recommendation, or favoring by the United States Government or any agency thereof. The views and opinions of authors expressed herein do not necessarily state or reflect those of the United States Government or any agency thereof. 


\section{DISCLAIMER}

Portions of this document may be illegible in electronic image products. Images are produced from the best available original document. 


\section{EXECUTIVE SUMMARY}

An assessment of potential vitrification technologies was performed during fiscal year (FY) 1994 to evaluate and select candidate melter systems that had high potential for successfully supporting the Tank Waste Remediation System (TWRS) mission. The assessment was primarily driven by the need to provide vitrification capacities in excess of those established for the original Hanford Waste Vitrification Plant. The assessment further provided an opportunity to assess innovative vitrification technologies for potential applicability to nuclear tank waste immobilization.

This assessment is the first step in selecting a reference melter system for the TWRS high-level waste (HLW) vitrification facility by September 1998 (Tri-Party Agreement Milestone M-51-02), and leads to initiation of definitive design in December 1998 (Tri-Party Agreement Milestone M-51-03-T02). This report documents results of the assessment activity and describes the process used to perform that assessment. It further documents recommendations that resulted from the assessment, summarizes the near-term path forward for implementation of the recommendations, and provides some initial estimates of the cost and schedule for the development and testing activities required to implement this recommendation.

The assessment process (Section 2.0) was established to provide a nonbiased, technically based evaluation of candidate HLW melter systems. This assessment was performed by a diverse cross-section of technical experts in commercial and HLW glass processing using a modified Kepner-Tregoe* problem

\footnotetext{
"Kepner-Tregoe is a trademark of Kepner-Tregoe, Inc.
} 
solving/decision-making process. The assessment team consisted of the following members.

- Five independent (non-Hanford Site) vitrification experts with extensive industrial, academic, international, and U.S. Department of Energy vitrification experience and expertise. These five members were referred to as the Technical Advisory Committee (TAC).

- Six Westinghouse Hanford Company (WHC) members representing various TWRS technical organizations. These members were referred to as the TWRS Technical Assessment Group (TTAG).

The TAC and TTAG members identified the candidate melter technologies, defined the assessment process and evaluation criteria, scored the melter technologies based on the evaluation criteria, and provided a balanced assessment of the candidate technologies. In addition, the TAC developed and prepared summary recommendations and conclusions from the assessment process.

Expert proponents of the various candidate melter technologies also attended the assessment workshop. These members were referred to as Technical Resource Staff (TRS). The primary function of the TRS, as well as various stakeholder groups (e.g., Washington State Department of Ecology; U.S. Department of Energy, Richland Operations Office (RL); and Yakama Indian Nation), was to provide additional technical input and other perspectives to the assessment process during criteria development and melter technology evaluation. 
Starting with 15 candidate melter system technologies, the assessment team narrowed the options for detailed consideration by performing an initial screening evaluation (Section 3.0). A draft recommendation on preferred melter technologies and technology development direction was prepared by the TAC following a more detailed and in-depth assessment of the screened technologies (Section 4.0).

Key elements of the TAC recommendation (Section 5.0) are as follows.

- All-electric, cold-top melters with nickel-based electrodes, developed initially at the Hanford Site and further developed for worldwide use, provide a solid base technology for HLW vitrification at the Hanford Site. These melters are being used at the Savannah River Site's Defense Waste Processing Facility, at the West Valley Demonstration Project in New York, in Japan, and at Belgium's highlevel waste PAMELA vitrification plant.

- Increased melter temperatures offer the potential for large reductions in total program costs. The first choice for increasing temperature is to develop higher temperature versions of the allelectric, cold-top melters by developing alternative hightemperature electrode concepts. Investigation of other methods for improving melter performance is also recommended, including agitation, feed drying, and use of sloped-melter bottoms for mitigation of sludge buildup.

- High-frequency induction melting offers the significant advantage of relief from problems of electrode attack, but should be considered a 
strong backup technology because of the relative immaturity of both the melters and power supplies. Initial testing should focus on potential compatibility issues specific to the high-pH, high-sodium level Hanford Site wastes.

- Other points of the recommendation focus on the need for development and testing of small- and large-scale test systems, cost/benefit considerations of the development program, and benefits of developing flexibility in the remote facility design to allow future installation of alternative technologies.

Using an established decision-making process, TWRS senior management reviewed and accepted the TAC recommendation and submitted it to RL for concurrence (Section 6.0). Westinghouse Hanford Company recommended that the results of the TAC assessment be accepted and implemented as the baseline HLW melter development approach. The RL concurred with that recommendation and directed WHC to formally adjust its baseline planning to implement the recommendation.

After obtaining RL concurrence, the melter system development and testing strategy and FY 1995 test requirements were established and used to develop overall cost and schedule requirements for development and testing activities leading to melter selection (Section 7.0). The melter system development and testing costs are estimated to average $\$ 11$ million per year from FYs 1995 through 1998. These estimates are based on projected costs of key integrated system testing activities and a schedule which supports the Tri-Party 
Agreement." These estimates do not include such testing activities as glass formulation, feed/process chemistry, and other engineering support activities.

"Ecology, EPA, and DOE, 1994, Hanford Federal Facility Agreement and Consent Order, as amended, Washington State Department of Ecology, U.S. Environmental Protection Agency, and U.S. Department of Energy. 
WHC-EP-0847

This page intentionally left blank. 
WHC-EP-0847

CONTENTS

1.0 INTRODUCTION AND SCOPE .................. 1-1

2.0 ASSESSMENT PROCESS ................... 2- . .

2.1 ASSESSMENT PARTICIPANTS - IDENTITIES AND ROLES ....... 2-1

2.2 EVALUATION PROCESS STEPS AND GENERAL ACCOMPLISHMENTS ..... 2-1

3.0 PHASE I ASSESSMENT AND EVALUATION PROCESS ........... 3-1

3.1 PHASE I CANDIDATE TECHNOLOGIES $\ldots \ldots \ldots . \ldots . \ldots . \ldots$

3.2 PHASE I SCREENING REQUIREMENTS $\ldots \ldots \ldots$

3.3 PHASE I CANDIDATE TECHNOLOGY ASSESSMENT PROCESS AND RESULTS : 3-3

3.4 RISK RATINGS AND BASES ................ 3-4

3.4.1 Low- to Moderate-Risk Technologies . . . . ..... 3-4

3.4.2 Moderate- to High-Risk Technologies ....... 3-7

3.4.3 High-Risk Technologies . . . . . . . . . . . 3-9

4.0 PHASE II EVALUATION .................. . . . . .

4.1 CANDIDATE TECHNOLOGIES EVALUATEd IN PHASE II $\ldots \ldots$

4.2 PHASE II EVALUATION CRITERIA ............ 4-1

4.3 PHASE II EVALUATION PROCESS . . . . . . . . . . . 4-4

4.3.1. Phase II Data Packages ........... . . 4-4

4.3.2 Phase II Assessment Process ......... 4-5

4.3.3 Phase II Evaluation Results and Rationale ...... 4-5

5.0 TAC RECOMMENDATION ...................... 5-1

6.0 EVALUATION CRITERIA AND DECISION-MAKING PROCESS ........ 6-1

7.0 MELTER DEVELOPMENT, TESTING, AND EVALUATION STRATEGY . ..... 7 -1

7.1 APPROACH . ................... 7-1

7.2 MELTER D\&T STRATEGY . . . . . . . . . . 7-2

7.2.1 Phased Nonradioactive Testing Approach . . . . . . 7-2

7.2.2 Radioactive Testing ............ 7- 7-6

7.3. REFERENCE MELTER SELECTION ............. 7-7

7.4 MELTER SYSTEM D\&T COSTS ............... 7-8

8.0 REFERENCES ..................... 8-1

9.0 GLOSSARY . . . . . . . . . . . . . . . GL-1 
WHC-EP-0847

CONTENTS (cont)

APPENDIXES

A MEETING PARTICIPANTS . . . . . . . . . . . . . . . . A-1

B TANK WASTE REMEDIATION SYSTEM DECISION BOARD MEMBERS AND STAKEHOLDER GROUPS ....................... B-1

c CANDIDATE MELTER TECHNOLOGIES .................. c-1

D TECHNICAL ADVISORY BOARD RECOMMENDATION LETTER . . . . . . . . . D

E TANK WASTE REMEDIATION SYSTEM DECISION BOARD RECOMMENDATIONS . . . . . E-1

F CONCURRENCE WITH HIGH-LEVEL WASTE MELTER ALTERNATIVES ASSESSMENT

DECISION .......................... F-1

\section{LIST OF FIGURES}

2-1 Melter Candidate Selection Participants . . . . . . . . . 2-2

4-1 Phase II Evaluation Criteria ............... . . 4-2

7-1. High-Leve1 Waste Me1ter System Development and Testing Assessment and Decision-Making Activities .............. . . 7-4

\section{LIST OF TABLES}

7-1 Estimated Melter Development Costs . . . . . . . . . . . 7-9 
WHC-EP-0847

HIGH-LEVEL MASTE MELTER ALTERNATIVES ASSESSMENT REPORT

\subsection{INTRODUCTION AND SCOPE}

This document describes the Tank Waste Remediation System (TWRS) HighLevel Waste (HLW) Program's (hereafter referred to as HLW Program) Melter Candidate Assessment Activity performed in fiscal year (FY) 1994. This assessment is the first step in selecting a reference melter system for the TWRS HLW vitrification facility by September 1998 (Tri-Party Agreement Milestone M-51-02) and leads to initiation of definitive design in December 1998 (Tri-Party Agreement Milestone M-51-03-T02).

The mission of the TWRS Program is to store, treat, and immobilize highly radioactive Hanford Site waste (current and future tank waste and encapsulated strontium and cesium isotopic sources) in an environmentally sound, safe, and cost-effective manner. The goal of the HLW Program is to immobilize the HLW fraction of pretreated tank waste into a vitrified product suitable for interim onsite storage and eventual offsite disposal at a geologic repository. Preparation of the encapsulated strontium and cesium isotopic sources for final disposal is also included in the HLW Program.

As a result of trade studies performed in 1992 and 1993, processes planned for pretreatment of tank wastes were modified substantially because of increasing estimates of the quantity of high-level and transuranic tank waste remaining after pretreatment. This resulted in substantial increases in needed vitrification plant capacity compared to the capacity of original Hanford Waste Vitrification Plant (HWVP). The required capacity has not been finalized, but is expected to be four to eight times that of the HWVP design. The increased capacity requirements for the HLW vitrification plant's melter prompted the assessment of candidate high-capacity HLW melter technologies to determine the most viable candidates and the required development and testing (D\&T) focus required to select the Hanford Site HLW vitrification plant melter system.

An assessment process was developed in early 1994. The assessment was performed during June through September of FY 1994, resulting in a recommendation to Westinghouse Hanford Company (WHC) senior management in October 1994. This document describes the assessment team, roles of team members, the phased assessment process and results, resulting recommendations, and the implementation strategy. 
WHC-EP-0847

This page left intentionally blank 
WHC-EP-0847

\subsection{ASSESSMENT PROCESS}

This section provides a summary of the assessment process, participants, and general accomplishments. The detailed Phase I and II process and process results and decision-making process are discussed in Sections 3.0 through 6.0.

\subsection{ASSESSMENT PARTICIPANTS - IDENTITIES AND ROLES}

The assessment process involved a Melter Selection Working Group (MSWG) consisting of Hanford Site and non-Hanford Site experts in commercial and HLW glass processing plus additional members knowledgeable of nuclear facility design and operations. The assessment team consisted of the following members.

- Five independent (non-Hanford Site) vitrification experts with extensive industrial, academic, international, and U.S. Department of Energy (DOE) vitrification experience. These five members were referred to as the Technical Advisory Committee (TAC).

- Six WHC members representing various TWRS organizations (Program Engineering, Projects, Operations, etc.). These members were referred to as the TWRS Technical Assessment Group (TTAG).

The assessment and decision-making participants and their roles and interactions are provided in Figure 2-1. The TAC and TTAG members were responsible for defining the assessment process and the evaluation criteria, scoring melter technologies to the evaluation criteria, and providing a balanced assessment of the candidate technologies. The TAC also developed and prepared summary recommendations and conclusions from the assessment process. In addition, Technical Resource Staff (TRS) supplied the MSWG with supplementary technical information concerning the technologies under consideration. The TRS included experts that have been involved in development of some of the technologies, and who are considered proponents of those technologies. The primary function of the TRS, as well as various stakeholder groups (e.g., Washington State Department of Ecology; U.S. Department of Energy, Richland Operations Office (RL); and Yakama Indian Nation), was to provide additional perspectives to the assessment process during criteria development and assessment processes. A TWRS Decision Board, consisting of TWRS senior management, approved the final recommendation and submitted it to RL. Appendix A provides a list of meeting participants, along with a brief discussion of their affiliations and areas of experience and expertise. The TWRS Decision Board members and stakeholder groups are listed in Appendix B.

\subsection{EVALUATION PROCESS STEPS AND GENERAL ACCOMPLISHMENTS}

The assessment was conducted in two phases. Each phase culminated in a workshop to bring the assessment team (TAC, TTAG, TRS, and stakeholder groups) together to perform the assessment and to document assessment results. The vitrification system identification, data/information compilation, and technology assessments were performed in 14 steps. Steps 1 through 5 comprised Phase I, steps 6 through 12 comprised Phase II, and steps 13 and 14 were completed after Phase II. 


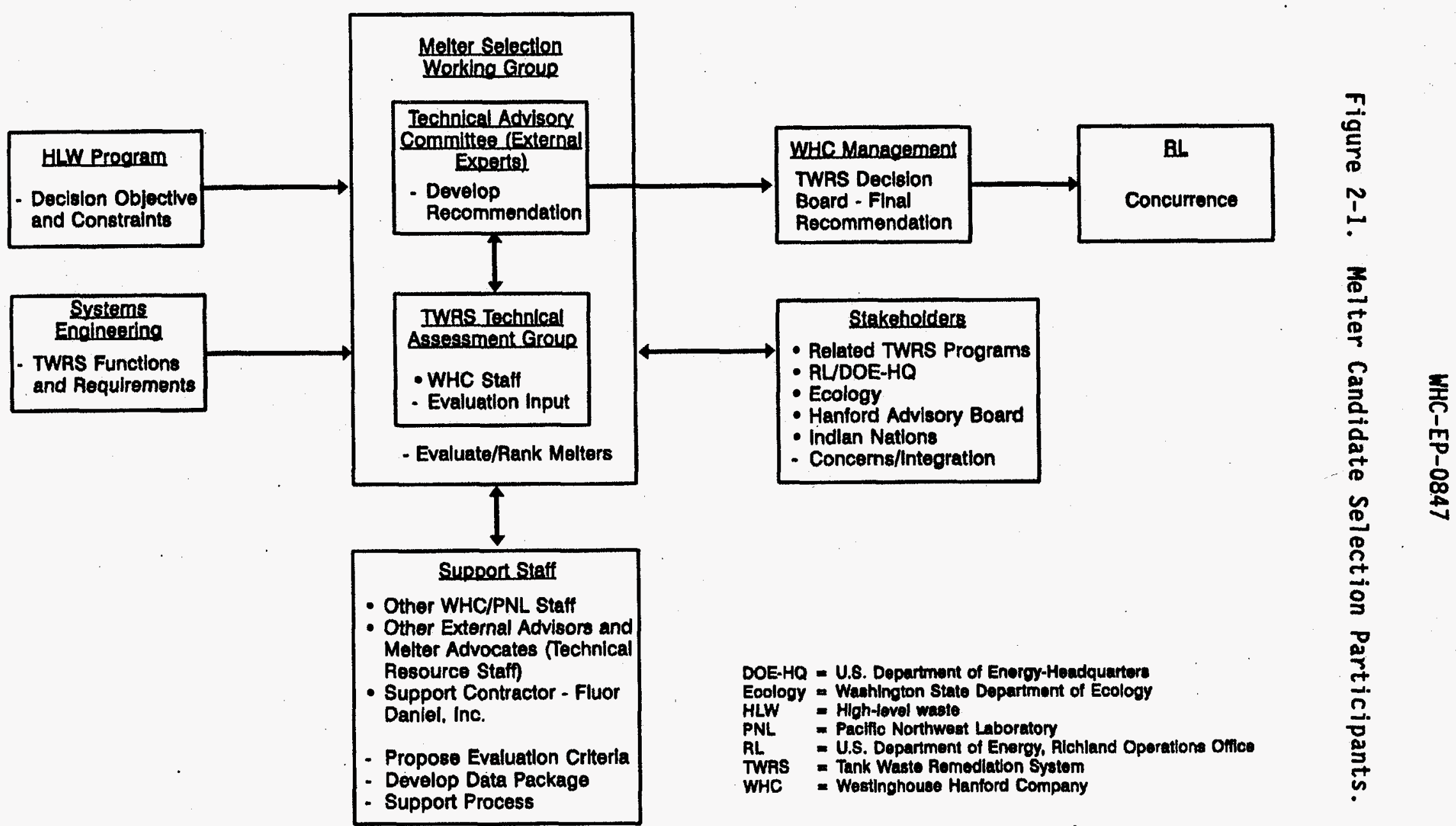


Step 1--Establish assessment process (Phase I)

The assessment process was established by Hanford Site technical staff before the Phase I workshop. The process was presented to the MSWG and subsequently modified and accepted.

Step 2--Identification and grouping of vitrification systems into technology groups (Phase I)

Technical staff from WHC and Pacific Northwest Laboratory (PNL) identified potential vitrification systems and grouped them according to defined technology groups. The MSWG provided input and review. Appendix C provides a brief description of candidate melter technologies considered.

Step 3--Identification of minimum melter technology evaluation requirements (Phase I)

The HLW Program and Hanford Site technical staff established minimum requirements (see Section 3.2), which were approved by the MSWG. The identified candidate melter systems were assessed relative to the minimum screening requirements (in Phase I) to determine the most viable Hanford Site HLW vitrification system candidates for additional in-depth assessment.

Step 4--Phase I screening evaluation of melter technologies (Phase I)

The MSWG performed a screening evaluation of the defined melter technologies to determine whether the vitrification systems met minimum HLW Program requirements. Melter technologies judged incapable of meeting minimum evaluation requirements were el iminated from further consideration. Data gathering for the eliminated technologies was terminated, and the primary basis for eliminating each technology was documented by Hanford Site technical staff and presented to the MSWG for review and concurrence.

Six (of 15) technologies were selected for further consideration based on their probability of success against the minimum requirements or screening requirements. The down-selected Phase I technologies were those judged to have the highest probability of success compared with the other alternative technologies.

Step 5--Identification of evaluation criteria (Phase I)

Key technical evaluation areas and system attributes were developed into evaluation criteria in Phase I. Initial criteria were proposed by Hanford Site technical staff. The MSWG reviewed these criteria and modified them to establish a basis for Phase II evaluation. The established criteria are presented in Section 4.2. In addition to establishing the final evaluation criteria, the MSWG established the down-selection and specific scoring methodologies. 
Step 6--Gathering information relative to each melter system technology (Phase II)

Phase II data compilation focused on specific technical areas and system attributes relative to each evaluation criterion. The criteria were developed to address the ability of the technologies to process a range of compositions, control product quality, develop technology on schedule, integrate with process and facility, control and maintain process and facility, minimize total cost, and minimize safety and environmental risks. Information was solicited from melter candidate vendors to supplement existing information/data available through open literature and glass industry experience.

Step 7--Compare available information with evaluation criteria, identify remaining questions, and make engineering estimates to answer remaining questions (Phase II)

Where information was unavailable or nonexistent, assumptions, predictions, and scoping evaluations were performed to provide information such as scaleup factors for offgas rate, glass production capacity, waste composition processing flexibility, scaleup factors, expected operability/maintainability, etc. The assumptions, predictions, and evaluations were primarily qualitative but represented best available information without performing extensive testing.

Cost estimates and evaluations were performed within funding and schedule constraints and were only performed for critical technical issues. The compiled information for each melter candidate, including estimates and predictions, was reviewed by the MSWG.

Step 8--Gather available information into packages for each melter system technology (Phase II)

Open 7 iterature information and data, vendor data, and engineering study results were compiled for each technology, and data packages were prepared by Hanford Site technical staff. The MSWG examined the data packages and engineering studies prepared between the first and second workshop.

Step 9--Present and review data packages with TAC (Phase II)

The TAC reviewed each data package and evaluated each key technical issue for adequacy.

Step 10--Evaluate melter technology groups with respect to the selection criteria (Phase II)

The MSWG scored each technology group with respect to the evaluation criteria in order to rank the technology groups and select those for further investigation in the Phase II evaluation. Melter technologies were then comparatively evaluated based on system attributes and expected system performance, and technical maturity for the proposed Hanford Site application. The data packages, MSWG expertise, and input from TRS provided the basis for scoring. This step included a criteria 
sensitivity check and generation of a listing of positive and negative attributes for each technology related to each criterion.

The MSWG assessed each technology against the criteria established in Phase I based on available technical information, input provided by the TRS, and expert judgement of the MSWG. Melter systems comprising each technology group include a wide range of features and subsystems that can be put together in many different combinations. To allow a tractable bas is for evaluations, a smaller number of systems concepts were selected for evaluation.

Step 11--MSWG evaluates individual melter candidates (Phase II)

The MSWG then scored individual melter systems within each defined technology group against the evaluation criteria in order to understand key discriminators between melter system candidates. Key discriminators identified by this process were then used as the basis for developing the overall recommendations for further testing and evaluation focus.

Step 12--Recommendation is generated by TAC (Phase II)

The TAC prepared a recommendation that reflects an MSWG consensus (TAC and TTAG) on vitrification technologies that should be carried into the D\&T activities as primary and backup technologies and the general direction of D\&T activities. The recommendation also included elements related to the overall development approach, the need for flexibility in facility design. to allow future melter technology evolution, and discussion relative to the reasons for not recommending technologies for further development (Phase I down selection). Development and testing of recommended technologies and key system features will establish the basis to select the HLW vitrification plant melter and support the detailed plant design.

Final recommendations were based on the strengths and weaknesses of the systems, including subfeatures. The final recommendation did not recommend specific integrated system concepts but rather recommended development of key desirable features identified in evaluating the integrated systems. The TAC recommendation letter is provided in Appendix D.

Step 13--Decision Board established vitrification system D\&T recommendation (post-Phase II)

The selection process and resulting TAC recommendation were reviewed by the TWRS Decision Board and a WHC-approved recommendation was submitted to RL for concurrence (Appendix E).

Step 14--Preparation of near-term implementation strategy (post-Phase II)

An implementation strategy for D\&T of the recommended technologies was prepared. Detailed test planning has been performed and testing initiated. 
Detailed descriptions of the Phase I and II assessment and evaluation processes and results are provided in Sections 3.0 and 4.0 , respectively. The TAC recommendation and TWRS decision-making process are discussed in more detail in Sections 5.0 and 6.0 , respectively. The implementation strategy and plans are described in Section 7.0. 
WHC-EP-0847

\subsection{PHASE I ASSESSMENT AND EVALUATION PROCESS}

This section discusses the Phase I candidate technologies, screening requirements, and technology assessment process and results.

\subsection{PHASE I CANDIDATE TECHNOLOGIES}

The following candidate technologies were identified and discussed during the Phase I assessment:

- Low-temperature $\left(\leq 1200^{\circ} \mathrm{C}\right)$, ceramic-lined, joule-heated melters (LTCM)

- Low-temperature, metal-lined, stirred, joule-heated melters

- High-temperature $\left(>1200^{\circ} \mathrm{C}\right)$, ceramic-lined, joule-heated melters (HTCM)

- High-temperature, metal-lined, joule-heated melters (cold and hot wa11)

- Low-frequency, metal-can, induction-heated melters

- High-frequency, cold-wall, induction-heated melters

- Plasma torches (entrained and indirect)

- Transferred-arc plasma melters

- Arc furnaces

- Conventional combustion melters

- Cyclone combustion melters

- Microwave melters

- Rotary kilns

- Hot isostatic presses

- In-can melters.

Appendix $C$ provides a sumnary description of each of the technologies.

\subsection{PHASE I SCREENING REQUIREMENTS}

A screening evaluation of each candidate technology was performed to determine the probability of each of the 15 candidate technologies to successfully meet the following minimum requirements: (1) produce a consistent, acceptable waste form; (2) be able to successfully develop required technology within TWRS Program constraints, including Tri-Party 
Agreement (Ecology et a1. 1994) milestone constraints; and (3) incur reasonable total program cost compared to other technologies.

The minimum melter system requirements for initial technology group screening are presented below. These requirement statements were used to develop abbreviated minimum requirement statements used in the workshop proceedings.

- The ability to meet minimum waste form specifications.

The Tri-Party Agreement establishes that the HLW form shall be a borosilicate glass or equivalent. Equivalent glass is interpreted to be a glass with equivalent durability or leach-resistance as compared with the reference Environmental Assessment glass." Melter system technologies judged to produce a glass waste form incapable of consistently meeting currently established glass acceptance criteria will be eliminated from consideration.

A reference HLW melter feed composition, representative of a nominal double-/single-shell tank blended feed, will be considered in the evaluation of each technology's ability to produce an acceptable glass waste form. In addition, the nominal feed and feed variability will be used as the basis to establish each system's ability to accommodate high waste oxide loadings and ranges of potential problem constituents (e.g., phosphorous, chromium, iron, etc.) that affect the glass product. Existing information/data and processing experience relative to producing acceptable glass products with Hanford Site waste feed types will be used to evaluate the system technologies/candidates.

- The ability to meet Tri-Party Agreement milestones.

Selection of a reference melter system must be completed by September 1998 in accordance with Tri-Party Agreement Milestone M-51-02, "Complete Melter Tests and Select Reference Melter." Viability of the melter system depends on the ability to develop and demonstrate the feasibility of the vitrification technology to process the required volume of Site HLW types and produce acceptable glass products within available program funding and schedule constraints. If technology development cannot be accomplished (key technical issues cannot be resolved or key system attributes confirmed) within program constraints, the candidate system technology will be el iminated from consideration. The key to assessing melter system technologies is recognizing each melter system's stage of development and the resources and time required to provide scaled system testing to identify and resolve key technical

-The current durability requirement is that the glass must have a boron release rate $<8.4 \mathrm{~g} / \mathrm{m}^{2} / 7$ days, a sodium release rate $<6.7 \mathrm{~g} / \mathrm{m}^{2} / 7$ days, a lithium release rate $<4.8 \mathrm{~g} / \mathrm{m}^{2} / 7$ days, and a silicon release rate $<2.0 \mathrm{~g} / \mathrm{m}^{2} / 7$ days for a crushed glass $(-100 /+200$ mesh) leach test (product consistency test) with a leachant volume to sample mass ratio of $10 \mathrm{~mL} / \mathrm{g}$ in deionized water at $90{ }^{\circ} \mathrm{C}$ for 7 days. 
issues. The actual evaluation relied on the judgement of the assembled team, which included a range of technical expertise and experience.

- Incur reasonable costs.

It is essential to process the required Site HLW feed volume during the plant's lifetime (December 2009 to December 2028) established in Tri-Party Agreement Milestone M-51-00, "Complete Vitrification of Hanford Site High-Level Tank Waste." Estimates were made of the melter technology's waste processing rate (function of glass production rate and waste oxide loading). In addition, a determination of potential impacts on plant design, plant operations, and processing flexibility was made. Those technologies that have excessive initial plant construction and/or operating cost impacts were eliminated from consideration. For example, prohibitively large numbers of parallel processing lines could result in excessive capital and operation costs.

\subsection{PHASE I CANDIDATE TECHNOLOGY ASSESSMENT PROCESS AND RESULTS}

For each requirement (product, schedule, cost), the MSWG and TRS assigned risk values of low, moderate, or high for each technology relative to the screening criteria. A technology with a high probability of success is referred to as a "low-risk" technology in this document. Likewise, a technology with a moderate or low probability of success is a moderate- or high-risk technology, respectively. The assessment group (MSWG and TRS) agreed that technologies with a combined number of "low" pius "moderate" risk assessments greater than, or equal to, the number of "high" risk assessments for all Phase I individual screening requirements would be considered candidates for follow-on consideration in the Phase II evaluation. Therefore, the established screening tally formula, or Phase I acceptance criteria, is: low-risk assessments + moderate-risk assessments $\geq$ high-risk assessments. The technologies that did not meet these acceptance criteria were then eliminated from further consideration. The assessment group retained the option of including technologies that did not meet the acceptance criteria on a case-bycase basis if judged to provide significant benefit if developed or if the technologies possessed unique features deserving further consideration. All 11 MSWG members assigned risk assessments; however, the number of TRS members assigning risk varied based on availability or expertise. A few examples of the use of the acceptance criteria and selection process are as follows.

1. The LTCM technology is the technology used at the Defense Waste Processing Facility (DWPF), the West Valley Demonstration Project, and other international facilities and was originally selected for the HWVP. Relative to meeting schedule requirements, this technology received 14 low-risk (L) assessments, 0 moderate-risk (M) assessments, and 0 high-risk $(H)$ assessments. Assessments were individually assigned by the MSWG and TRS. Applying the acceptance criteria, $14 \mathrm{~L}+0 \mathrm{M}>0 \mathrm{H}$, the assessment group determined that this technology met the Phase I minimum schedule requirement. This technology also received combined low- and moderate-risk assessments 
higher than the sum of high-risk assessments relative to each of the other two requirements. The technology was therefore included in the Phase II in-depth evaluation.

2. The low-frequency, metal-can, induction-heated melter technology was assigned the following risk assessment relative to meeting the Phase I cost requirement: $0 \mathrm{~L}, 8 \mathrm{M}$, and $9 \mathrm{H}$. The cumulative number of low- and moderate-risk assessments was lower than the high-risk assessments; therefore, this technology did not meet the Phase I acceptance criteria reiative to the cost requirement and was subject to being eliminated from further consideration. At the end of the assessment, however, the MSWG voted on whether any of the eliminated technologies should receive further consideration based on unique features or potentially significant benefits. This technology was the only technology not meeting the acceptance criteria that was later added to the list of technologies being considered in the Phase II in-depth evaluation. This was done primarily because this technology has been successfully used for vitrifying HLW reprocessing waste in France and England.

3. The cyclone combustion melter technology was assigned the following overall risk assessment: $0 \mathrm{~L}, 1 \mathrm{M}$, and $16 \mathrm{H}$. The risk assessment for this technology was based on an assessment of overall risk (not to individual product, schedule, or cost requirements) due to the extensive and significant unresolved fundamental technical issues associated with this technology. These issues were judged to have a significant impact on cost and schedule associated with technology development well beyond TWRS Program constraints, so much so as to be untenable as an HLW melter system candidate. This technology was considered an unacceptable high risk and was therefore eliminated from further consideration in the Phase II evaluation.

The risk assessments for each technology can be grouped into three categories: low to moderate risk, moderate to high risk, and high risk. Five of the technologies were clearly lower-risk technologies relative to the screening criteria. These five technologies and one moderate- to high-risk technology (low-frequency, metal-can, induction-heated melter) were selected for further assessment in the Phase II evaluation.

\subsection{RISK RATINGS AND BASES}

Summary discussions of each of the 15 Phase I candidate technology groups and the basis for the overall risk rating are presented in the following subsections. The summary discussions reflect the primary discussion points that led to the risk assessment tallies and overall comparative rankings.

\subsubsection{Low- to Moderate-Risk Technologies}

This section provides a summary of the low- to moderate-risk technologies identified in Section 3.3.1 and the basis for the overall risk rating. The technologies identified in this section are the technologies included in the Phase II in-depth evaluation. In Phase II, each of the technology's attributes received additional comparison to detailed evaluation criteria. 
The following discussion provides the consensus MSWG position for assigned risk ratings during the Phase I evaluation. Additional discussion of these systems is presented in Appendix $C$.

3.4.1.1 LTCM. The LTCM is a proven remote melter technology that has demonstrated its ability to reliably produce a consistent, acceptable quality HLW glass product. This technology provides passive operation, low maintenance, and ease of operation using materials of construction proven in various $H L W$ feed compositions. In addition, many test units are available at various scales, e.g., German K6', integrated DWPF melter system, LTCM at PNL, etc. The availability of test units, in conjunction with the added benefit of information and operating experience from projected cold runs and radioactive testing to be performed at the DWPF and facilities in Belgium, Japan, Russia, and India, provides reasonable assurance that development schedules can be met relative to selection of a reference melter. Most of the operational, reliability, and performance-based technical issues associated with this technology either have been resolved or have a high potential to be resolved with low-risk design changes.

The primary technical issues associated with this technology are: (1) lifetime of the melter due to sludge accumulation on the melter floor, (2) limited waste oxide loading (resulting in higher canister disposal costs relative to higher temperature technologies), and (3) large melter size, which could result in high melter disposal costs.

It is expected that the sludge accumulation issue can be resolved. Designs to remediate these issues are already being pursued in and outside the United States with reasonable success. The Germans have designed a slopedbottom melter with an inductively heated bottom drain to remediate their noble metals/sludge buildup problem.

3.4.1.2 Low-Temperature, Metal-Lined, Stjpred, Joule-Heated Melters (Stirred Melter). The stirred meiter (Inconel $690^{\circ}$ stirrer and pot) system is compact and modular with potentially high glass production rates. In addition, the positive results of small-scale evaluations of this technology for use in HLW applications, the availability of test units with remote features and support equipment, moderate probability that key technical issues can be resolved within program constraints, as well as the perceived high probability of success, were key to the low- to moderate-risk assessment of this technology.

This technology has been evaluated as a second generation melter for the DWPF at the Savannah River Site (SRS) with small-scale testing conducted using SRS waste-type simulants. In addition, a pilot-scale test unit is being constructed at the SRS with HLW simulant testing scheduled in FY 1996. Smal1scale testing using mixed-waste simulants has also been conducted at Clemson University under contract to SRS.

The primary technical issues identified are (1) scaleup of the technology, (2) materials life, (3) potential operating and performance limitations due to the stirring system, (4) unproven glass-holding tank design and operation, and (5) limited waste oxide loading (resulting in higher canister disposal costs relative to other potentially higher temperature

*Inconel is a trademark of INCO Alloys International, Inc.. 
technologies). Ability to scale up the technology was not perceived to be a limiting issue. It is reasonable to assume that, in the worst case, the number of units would increase but not to an unacceptable number. This was not judged to be limiting from a facility or cost standpoint. The low melter operating temperature $\left(1050^{\circ} \mathrm{C}\right)$ and positive small-scale testing results indicate that materials performance from stirring will be manageable. However, there is some concern that high-phosphorous feeds could attack the Inconel 690 stirrer and pot. Materials compatibility was not judged to be nearly as big an issue as potential materials problems resulting from hightemperature metal attack and was thought to be a low to moderate risk in comparison. Operation and performance of the system need to be developed.

3.4.1.3 HTCM. The HTCM will have many of the same advantages as the LTCM. This includes the ability to incorporate proven remote design features, passive operation, low maintenance, and ease of operation. In addition, bench- and pilot-scale test units are available for testing to resolve many technical issues and concerns. Availability of test units, e.g., at the PNL and Clemson University, provide reasonable probability that development schedules supporting the Tri-Party Agreement milestones could be met. Many similar HTCMs are operating in the commercial glass industry and have successfully produced large quantities of high-quality glass. These types of melters are capable of good temperature control and operate with a batch blanket (cold cap) which inhibits volatilization of high vapor pressure constituents. In addition, the higher operating temperatures may accommodate higher waste loadings resulting in lower total glass product for disposal.

Resolution of the electrode materials issue is key to the success of this technology. Other major issues associated with this technology are the potential for sludge buildup, materials compatibility, waste component volatilization, and moderately high failed melter disposal costs. Various materials are being investigated to replace the reference molybdenum electrodes and bottom-drain materials to establish longer life or permanent electrode materials. Recent data indicate molybdenum electrodes may need to be fed into the melter or periodically replaced due to corrosion/erosion in Hanford Site feeds. Alternate materials include coated molybdenum, platinum group alloys, and proprietary materials and configurations. The MSWG agreed that although verification of alternate electrode and refractory materials could be a costly activity, the risk to schedule and cost was moderate because materials issues may be resolved with a combination of laboratory-, small-, and pilot-scale melter testing. If useable electrode and bottom-drain materials are confirmed, the technology could be a low-risk technology. Waste component volatilization was predicted to be not much higher than the jowtemperature experience base, and is not predicted to be nearly as significant as for combustion/plasma technologies.

3.4.1.4 High-Temperature, Metal-Lined, Joule-Heated Melters (Cold Wa11). The high-temperature, metal-lined, joule-heated, cold-wall melters were generally viewed as a variation of the HTCM technology, only without refractory erosion/ corrosion issues. This technology has been developed for specific applications in commercial industry and was deemed to warrant further data compilation and assessment. Though conceptually very promising, the development status and specific design features of this technology needed to be better defined. Without sufficient development status information, the MSWG assumed this technology could be developed within schedule constraints and was judged to have a low to moderate probability of success. 
3.4.1.5 High-Frequency, Cold-Ha11, Induction-Heated Melters (Cold-Crucible Melter [CCM]). The CCM system is reported to be capable of operating at temperatures (above $1550^{\circ} \mathrm{C}$ ) with a long projected melter life. To attain maximum production capacities (expected maximum is about $200 \mathrm{~kg} / \mathrm{h}$ with $1.2-\mathrm{m}$ diameter melter), it is anticipated that the melter will require coupling to a feed drying system (e.g., calciner, horizontal, or vertical wiped film evaporator). This technology, with close-coupled rotary calciner, is being evaluated for HLW vitrification in France (scale melters of $0.55 \mathrm{~m}$ and $50 \mathrm{~kg} / \mathrm{h}$ to production-scale melters with $1.2-\mathrm{m}$ diameter and $200-\mathrm{kg} / \mathrm{h}$ glass production capacity). The Russians are also reported to be operating three $30-\mathrm{kg} / \mathrm{h}$ remote radioactive units with close-coupled, vertical, wiped-film evaporators. The high-temperature capability of this technology, the existence of HLW test systems, and life-cycle cost advantages associated with long melter life are the main reasons this technology was assessed as low to moderate risk.

Key technical issues that need to be assessed are calciner/melter performance with the Hanford Site's blended feeds, extent of glass mixing and glass product quality, production capacity, and bottom-drain performance. The only issues considered to be high risk are calciner performance with viable alkaline feeds and bottom-drain performance. Significant testing will be required to confirm calciner performance with various feed types. The French claim to have a proven proprietary bottom-drain valve for use in their high frequency melter.

\subsubsection{Moderate- to High-Risk Technologies}

This section discusses the moderate- to high-risk technologies identified in Section 3.4.3.2 and the basis for the overall risk rating.

3.4.2.1 Low-Frequency, Metal-Can, Induction-Heated Melter. The lowfrequency, metal-can, induction-heated melters are most suitable for vitrification of low volumes of acidic HLW. Numerous technical limitations make operation of this technology complex and costly for processing high throughputs of HLW. The primary technical issues relative to this technology are limited production capacity (approximately $25 \mathrm{~kg} / \mathrm{h}$ per unit); the resulting large number of production units required to meet Hanford Site production goals; costly facility, maintenance, and disposal costs; and short melter life ( $<2,000$ hours). These limitations, together with uncertainties about the ability of the calciner to handle a range of alkaline feeds and consistently produce quality products, are somewhat offset by the technology maturity, availability of test units, and established remote radioactive plant operation associated with operating HLW vitrification plants in England and France. This technology was assessed as a moderate risk. However, the MSWG decided that if the operating complexity issue, materials issues, and calciner performance could be worked, the technology's maturity may provide significant benefit. This technology was considered with the low- to moderate-risk technologies to provide, at a minimum, a basis for comparison.

3.4.2.2 Plasma Torches (Entrained and Indirect). The plasma torch-based technologies provide high throughput rates, have application for melting of solid wastes (metal/soil/clothing, etc.), and are well developed and tested for these applications. However, entrainment of the feed in the plasma presents an unnecessarily high risk of reduction and volatilization of feed components. For HLW streams, where high volatility can be a significant 
problem, these technologies have a moderate to high risk of being adaptable to processing HLW feed types and of being developed within TWRS Program constraints.

Use of a plasma to indirectly heat the feed was judged to present less risk of volatilization than the entrained plasma method and cyclone combustion processes, and presents a lower volume of offgas than the conventional combustion heating.

The plasma torch-based technologies subject the feed to high operating temperatures $\left(3000{ }^{\circ} \mathrm{C}\right.$ plus), which results in high volatility and entrainment of feed constituents. The high volatility issue warranted the high-risk assessment because the development effort to design a system that could recycle or remediate the volatile offgas species streams would be significant and would be difficult to accomplish within TWRS Program constraints.

In addition to high volatility, other significant issues include maintenance of the torches in a remote radioactive environment, glass quality from inefficient melting (without a heated glass-holding chamber with at least 4 hours of residence time), and control of glass product (because of high volatility). An additional disadvantage is the almost total lack of testing or operating experience with feeds in any way similar to the Hanford Site HLW. This creates the likelihood that there are other technical issues that have yet to be identified.

3.4.2.3 Transferred-Arc Plasma Melters. Transferred-arc plasma melters provide high-throughput rates, have application for melting of solid wastes (metal/soil/clothing/etc.), and are well developed for these applications. However, for HLW streams, where high volatility can be a significant problem, these technologies have a moderate to high risk of being adaptable to processing HLW feed types and of being developed within TWRS Program constraints.

This technology subjects the waste feed to high operating temperatures ( 3000 "C plus). One adaptation (the "submerged arc") has advantages over the plasma torch technologies in that electrodes (usually graphite) can be operated in a submerged mode reducing somewhat the volatilization, and heating of the melt is more uniform due to the addition of joule heating. The high volatility issues warranted the moderate- to high-risk assessment rating because the development effort to design a system that could recycle or remediate the volatile offgas species streams would be significant and would be difficult to accomplish within TWRS Program constraints. Many components of $H L W$ are easily reduced to metal vapors (e.g., cesium, cadmium, zinc) in the presence of hot graphite, thus increasing the risk of losses by volatilization. Formation of a molten metal pool in the melter is also a potential problem with this technology.

In addition to high volatility, other significant issues include maintenance of the torches in a remote radioactive environment, glass quality from inefficient melting (without a heated glass-holding chamber with at least 4 hours of residence time), and control of glass product (because of high volatility, nonuniform temperature, and limited mixing).

3.4.2.4 Arc Furnaces. The arc furnaces operate much like the plasma arc melters, have many of the same problems without many of the previousiy 
WHC-EP-0847

discussed advantages, and were assessed to have high risk. Also, no previous testing or detailed evaluation has been demonstrated for application to HLW vitrification.

\subsubsection{High-Risk Technologies}

This section provides a summary discussion of the high-risk technologies and the basis for the overall risk rating.

3.4.3.1 High-Temperature, Metal-Lined, Joule-Heated Melters (Hot Wall). This melter technology is considered to be a high risk due to the low probability that a metal lining could be designed to be compatible with corrosion/erosion rates expected with the convective currents and feed composition associated with the HTCM and double-/single-shell tank feeds. This melter is expected to have a short life with little difference in the cost between a conventional refractory-lined melter and metal-lined melter. There is essentially little benefit in developing this technology in lieu of the more developed hightemperature, refractory-lined, joule-heated melter technologies, which have significantiy less risk with the same advantages.

3.4.3.2 Conventional Combustion Melters. The conventional combustion melter technology has been used extensively in the commercial glass industry and is a well-developed commercial process. However, this technology would require extensive development before it could be used in a remote radioactive environment. The probability that key technical issues could be resolved within TWRS Program constraints is doubtful (high risk). In addition, the group agreed that many identified technologies have much more promise with comparatively lower risk. Technical issues relative to this technology are volatility of high vapor pressure feed constituents, potentially highmaintenance flame nozzles, potential sludge buildup due to melter pool thermal gradients, large total offgas volumes, and development and evaluation of design features and defensible pedigree to ensure safe operation (fuel/air or oxygen mixtures) in a remote, radioactive environment.

A fundamental limit of this technology is the amount of volatilization. The heating method limits cold-cap coverage and allows for high vapor pressure feed constituent volatilization in the operating temperature range. In addition, the large offgas quantities put a significant burden on the melter offgas system. Because this technology does not have electrodes, much of the electrode materials issues do not exist; however, these issues are overshadowed by the need to maintain combustion gas burner nozzles. The conventional combustion melter is large and is comparable to ceramic-lined melters with comparable disposal costs. In general, the high-risk assessment was based on the premise that it would take many years and more money than available to develop this technology to the extent that it could be considered viable for HLW vitrification.

3.4.3.3 Cyclone Combustion Melters. The cyclone combustion technology was judged to be at an early stage of development relative to vitrification of HLW feeds and would require extensive testing and development to identify and resolve numerous key technical issues/concerns. This technology has no current industrial application and has not been demonstrated, or employed, in any industrial application to determine system production capability. There are many unresolved technical issues and likely many technical issues that 
have not been identified due to lack of prior operation with water-based slurry feeds. There is also no experience with the range of components present in Hanford Site HLW feeds. This technology was judged to have a low probability of being successfully developed within TWRS Program constraints. In addition to resolving melter performance-based issues, it also would be necessary to resolve design and operational features and regulatory issues required to ensure the technology could be safely operated (fuel/oxygen mixtures) in a remote HLW processing plant.

The following technical issues, as judged by the assembled experts, are cited as examples that the high-risk assessment was warranted: (1) extensive design and testing to develop feed system technology; (2) risk of being able to develop offgas cleaning and waste treatment systems to remediate/recycle the high quantity of offgas volatiles; (3) extensive testing necessary to determine operational durability, extent of necessary maintenance, materials performance, and to identify any operations or performance problems which may exist; and (4) difficulty in controlling glass composition and quality due to evaporation of a significant fraction of the glass-forming components.

3.4.3.4 Microwave Melters. Microwave melters are 1 imited to heating sma11 quantities of materials very fast. The high-frequency ( 25 to $50 \mathrm{MHz}$ ) microwave systems have little penetration depth and are therefore only capable of heating a very thin layer of molten conductive material on the melt surface. This technology is not conducive to melting at high-production rates, and was not considered by the group to be a candidate for vitrification of HLW when compared to other low-risk technologies.

3.4.3.5 Rotary kilns. This technology is a variation on the conventional combustion method, having all its disadvantages plus additional maintenance issues. This technology was assessed as a high-risk technology primarily because of large maintenance requirements which are not conducive to remote radioactive operation, high volatility, large size, and high volatility. This technology was viewed to have no application in a remote environment and is not considered a viable HLW melter system candidate.

3.4.3.6 Hot Isostatic Presses. Hot isostatic presses technology uses dry powders as feed to a high-temperature compaction operation. Difficulty in controlling powder particle size and mixing of waste feed and glass formers to produce a homogeneous glass product meeting acceptable glass definitions and performance specifications are key concerns relative to the ability to maintain and control an acceptable glass product. The primary reasons this technology was assessed as a high-risk technology were glass quality and waste form qualification concerns, the ability to develop equipment with acceptable maintenance characteristics, low waste processing rates, and ability to scale up equipment.

3.4.3.7 In-Can Melters. Previously developed in-can melter technology has low production rates. This technology could have some merit for low-volume problem feeds but is unreasonable for the high capacities associated with the primary vitrification mission for Hanford Site HLW. Some general deviations to the in-can melter design previously developed were discussed, but D\&T of such concepts are not judged to be remotely possible within current Tri-Party Agreement milestone restrictions. Key issues judged to require significant effort to resolve are scaleup, resolving waste form qualification and process/product control (e.g., sampling, homogeneity, low durability [low 
temperature]), and canister integrity. The in-can melter is also judged to have high cost relative to other viable options because of the large numbers of trains required to meet plant capacity requirements. 
WHC-EP-0847

This page intentionally left blank. 


\subsection{PHASE II EVALUATION}

This section describes the Phase II evaluation criteria, the technologies selected for in-depth evaluation in the Phase II assessment, the contents of a typical Phase II data package, and the rationale used to assess and down select Phase II technologies.

\subsection{CANDIDATE TECHNOLOGIES EVALUATED IN PHASE II}

The following technologies were selected for in-depth evaluation during the Phase II assessment:

- LTCMs

- Low-temperature, metal-1ined, stirred, joule-heated melters

- HTCMs

- High-temperature, metal-lined, joule-heated melters (cold wall)

- Low-frequency, metal can, induction-heated melters (10w temperature)

- High-frequency, cold-wall, induction-heated melters (high temperature).

Appendix $C$ provides a more detailed description of each technology.

\subsection{PHASE II EVALUATION CRITERIA}

General criteria and criteria attributes were developed at the conclusion of Phase I for use in the Phase II evaluation. The following is a summary of the criteria and their definitions established by the MSWG. In addition, the criteria and the specific attributes which were addressed relative to each criterion are presented in Figure 4-1 in an outline tree format.

\section{Phase II Evaluation Criteria}

- Process a range of compositions

- Flexibility to process expected waste compositions within melter operating parameters

- Control product quality

- Consistent glass product with a controlled composition

- Melter system design or performance characteristics that improve or limit ability to produce a consistent, predictable product with the desired composition and properties 


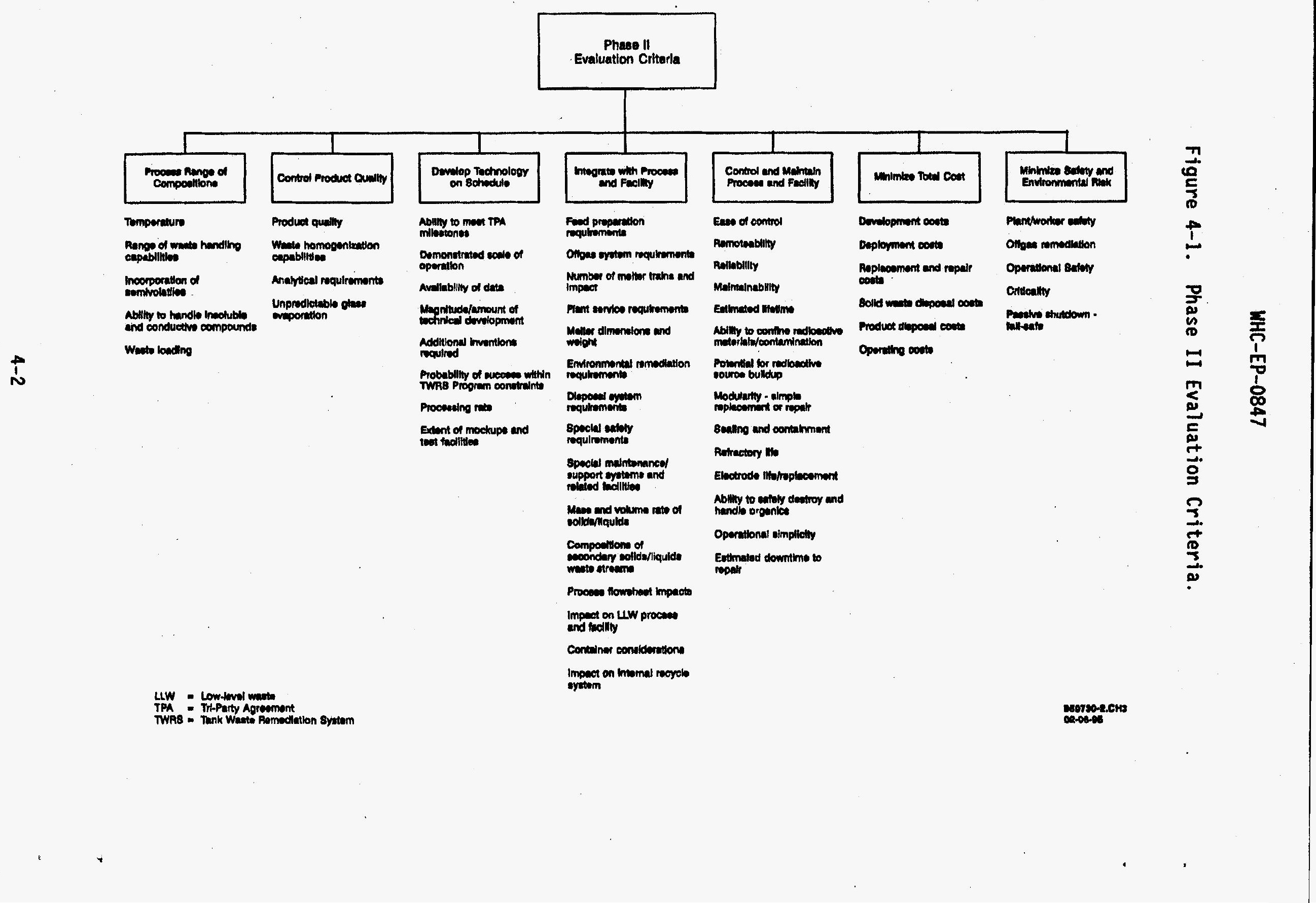


- Develop technology on schedule

- Basis to develop technology to the point that key technical issues are resolved within schedule constraints

- Features of technology carrying a high degree of risk

- Options to reduce technical risk, within schedule, to the point that the technology can be considered a viable HLW vitrification $\mathrm{plant}$ melter system for incorporation into detailed design

- Integrate with process and facility

- Ability to integrate easily with upstream and downstream processing steps as well as facility constraints

- Ability to meet requirements placed on the balance of plant and support systems (e.g., facility size, maintenance systems, safety mitigation systems, offgas, canister handling, waste handling and disposal, and secondary waste treatment systems) by the proposed HLW vitrification technology and unique process flowsheet features

- Control and maintain process and facility

- Ability to easily control and maintain the process and facility

- Design features related to remote operation and maintenance (such as the ability to drain the melter if required), the ability to replace parts, and the potential for performing these operations remotely

- Operational simplicity, compactness of design, passive features, and the number of moving or consumable parts

- Suitability of the melter system for operation and maintenance in a radiologically controlled environment

- Expected operating lives for melter and radioactivecontaminated support equipment and ease of disposal

- Size and quantity of contaminated equipment and materials requiring disposal

- Minimize total cost

- Provide the required product at a minimum cost to the HLW Program

- Design features and requirements that significantly affect life-cycle costs, such as development costs, melter system disposal, secondary feed stream and equipment disposal, consumable parts, energy and utilities requirements, glass former materials or feed additives, and quantity of glass produced (glass product disposal costs) 
- Minimize safety and environmental risk

- Ability of melter system to operate safely in a remote environment

- Probability and consequences of unsafe or costly upset event

- Consider other risks and limitations

- Risk to schedule based on resolving institutional barriers

- Unusual and/or special considerations.

\subsection{PHASE II EVALUATION PROCESS}

This section discusses the information used to define the candidate Phase II technologies and the Phase II assessment process and results.

\subsubsection{Phase II Data Packages}

Data packages for each of the Phase II technologies were prepared for use by the assessment team from open literature and direct vendor information and technical experience to provide a baseline from which to perform the assessment. The data packages included the following information: (1) a detailed description of the technology and unique system features, (2) best available data/information relative to established Phase II evaluation criteria and system attributes, and (3) engineering balance-of-plant studies, which evaluate potentiaily significant impacts to facility and supporting systems and system equipment.

The portion of the data package specific to the vitrification system was prepared by cognizant PNL staff and was compiled from open literature specific to the general technology group and from nonproprietary vendor information. An effort was made to obtain vendor or developer information related to specific discriminating features within each technology group. The PNL section of each data package was reviewed for adequacy by WHC TWRS technical staff and independentiy reviewed by cognizant technical staff from the SRS. Where data were not available, it was so noted in the packages. Each piece of information was referenced so the MSWG would know the origin of the data.

Engineering studies were performed by Fluor Daniel, Inc. to assess the impact of different vitrification system technologies on balance-of-plant equipment and the plant facility. The balance-of-plant studies focused on expected key cost discriminators: melter system failed equipment handling and disposal, facility size (e.g., melter cell, failed equipment cutup cell, transport corridors, and crane requirements), and feed preparation and offgas systems. In summary, the study found that the effect of melter technology selection on initial plant cost was relatively small compared to total projected facility capital and operating costs. The study also found that the cost of providing facility flexibility to allow use of multiple melter types is relatively small when compared to total HLW vitrification plant life-cycle costs, provided this flexibility is included during plant design. 


\subsubsection{Phase II Assessment Process}

Each technology was evaluated against the Phase II evaluation criteria to establish a comparative ranking for each major criterion. The Phase II assessment process included the following key activities related to comparing the technologies to the evaluation criteria.

- Identify and discuss each technology's key strengths and weaknesses relative to each criterion.

Each technology's strengths and weaknesses were identified by the MSWG and discussed relative to each criterion.

- Score the technologies against specific criteria, as discussed in Section 4.3.3.

The technologies were numerically scored against each criterion and then comparatively ranked by the MSWG and technical staff. Individual attributes were also scored when required for clarity and discussion. Individual scoring results for each technology were used to promote further detailed discussion and to provide the basis for a final numerical consensus score for each technology against each evaluation criterion. The scoring process also highlighted key issues, perspectives, and technical positions of assessment group members. The consensus scores reflected by the MSWG's expert opinion of each melter technology's relative performance according to each criterion.

- Perform an overall assessment of all technologies to provide a recommendation that can be used to establish a technically sound, cost-effective, success-oriented melter system development plan.

Once the evaluation and scoring were completed, general trends were identified and an overall assessment of the scoring results was performed by the MSWG.

- Review and discuss the TAC recommendation with Hanford Site members of the MSWG.

After review and comment resolution, the TAC recommendations were adopted by the entire. MSWG with minor editorial modifications.

\subsubsection{Phase II Evaluation Results and Rationale}

In summary, two of the technologies [(1) the high-temperature, metallined, joule-heated melters (cold-wal1); and (2) the low-frequency, metal can, induction-heated melters] scored well below the other four Phase II technologies relative to the majority of criteria. The MSWG reached consensus to el iminate these two technologies from consideration as potential HLW melter system technologies.

The high-temperature, metal-lined, joule-heated (cold-wall) melter system was el iminated based primarily on fundamental technical concerns with control of bulk melter temperatures, electrode performance, product quality, and the 
relative immaturity of the technology for HLW vitrification. While this technology is conceptually very appealing, there is a shortage of technical data and relevant operating experience. Extensive D\&T would be required to provide enough technical data to assess technical feasibility.

The low-frequency induction technology was eliminated based primarily on cumulative fundamental concerns regarding required feed drying of Hanford Site alkaline feeds, limited operating temperature resulting in significant glass volumes and high disposal costs, and the large number of units that would be required to process the significant volume of Hanford Site HLW. The large number of required melter systems and supporting equipment would pose significant challenges in designing, operating, and maintaining such a plant.

The expert judgment of the MSWG and TRS was that pursuit of these two technologies would be unreasonable compared to the other more promising mature technologies possessing a much higher probability of success.

The TAC used data generated during the assessment, meeting discussions, evaluation criteria, and criteria weighting to perform a balanced assessment of the remaining four technologies. This "stand back and look at the overall picture" approach was used to develop TAC recommendations for a focused D\&T strategy.

Based on the scoring results, it was apparent that key discriminators among the remaining four technologies were the development status of the technologies and the operating temperature regime, which influences waste processing flexibility and total volume of glass product requiring disposal, a key cost discriminator. The TAC recommendation also identified these as the major items influencing regrouping of the final four technologies and the basis for selection of primary and backup technologies. 


\subsection{TAC RECONMENDATION}

The TAC developed its recommendation using the assessment and scoring results applied to the four Phase II down-selected technologies and focused the recommendation on technical areas expected to provide the most benefit to the HLW Program.

The TAC recognized that the four down-selected technologies were defined to promote evaluation of the technology's features and capabilities and to highlight key advantages/disadvantages related to specific key technical features. However, the TAC concluded that a broader classification of the four technologies was needed to allow a phased and flexible D\&T approach. Therefore, the TAC reclassified the remaining technologies to allow development of key system features and technical areas, rather than define development in terms of the specific melter system concepts defined in the evaluation process.

The final four technologies were regrouped by the TAC into one primary technology, namely electric joule heating with electrodes, with three variants, and a backup technology, namely high-frequency induction heating. The primary technology was judged to provide a solid technical base for HLW vitrification of Hanford Site wastes with reasonable plant life-cycle costs. High-frequency induction melting was judged to be a strong backup technology due to its maturity relative to vitrification of $H L W$, the benefit of hightemperature operation, and potential for long melter 1 ife. This technology was recommended as a backup technology due to its lack of test data with Hanford Site feed, need to dry the melter feed to provide required capacity, and lack of large-scale system development and power supply development. The TAC recommendation, including conclusions and recommendations relative to the D\&T of the primary and backup technologies, and discussion of technologies not recommended for further development are provided in Appendix $D$.

A summary of the rationale for each specific recommendation is provided in the TAC recommendation letter presented in Appendix D. The HLW Program's melter system D\&T strategy developed to implement the TAC recommendations is provided in WHC-SD-WM-SD-007, Tank Waste Remediation System High-Level Waste Vitrification System Development and Testing Strategy (Calmus 1995a). 


\section{WHC-EP-0847}

This page intentionally left blank. 


\subsection{EVALUATION CRITERIA AND DECISION-MAKING PROCESS}

A group of WHC senior management (TWRS Decision Board) was established to provide the final decision of which technologies and D\&T path forward to recommend to RL for concurrence. The Decision Board members are listed in Appendix B.

The TAC recommendation, with TTAG concurrence, was presented to the TWRS HLW Program Office management with supporting data and rationale. The TWRS HLW Program Office agreed with the recommendation and presented the recommendation and supporting information to the TWRS Decision Board. The Board reviewed the final assessment process used, the evaluation criteria, and scoring and ranking data and criteria weightings as reflected in the TAC recommendation letter. The TWRS Decision Board agreed with the TAC recommendation and prepared the final WHC recommendation (Appendix E) for RL concurrence. The RL subsequently concurred (Appendix F) with the WHC recommendation with no requested modifications and instructed WHC to proceed with implementation. 


\section{WHC-EP-0847}

This page intentionally left blank. 


\subsection{MELTER DEVELOPMENT, TESTING, AND EVALUATION STRATEgy}

The HLW melter assessment recommendation generated changes to the HLW melter development, testing, and evaluation strategy that are documented in detail in WHC-SD-WM-SD-007 (Calmus 1995a). This section summarizes the strategy of the HLW melter D\&T program and shows how it supports the HLW vitrification plant reference melter selection.

\subsection{APPROACH}

The overall strategy is based on general testing activities used to develop melter systems at the SRS and other international melter system development programs for radioactive waste immobilization. The general approach is to test melter systems in a phased program. The smallest, most cost-effective test systems that use nonradioactive simulants are needed in the initial phases to resolve key technical issues generally associated with process chemistry, process performance, feed processibility, and glass product behavior. In the later phases, large-scale nonradioactive test systems are needed to confirm small-scale test results and demonstrate plant-scale performance and operability. Testing with radioactive waste feeds is typically limited to small-scale systems to develop the necessary correlation between HLW nonradioactive simulants and actual radioactive waste feeds relative to process chemistry, feed processibility, and glass product performance.. All phases of testing are timed to provide the data to support key HLW Program decisions.

The key elements of the new HLW vitrification melter system testing strategy are as follows.

- Establish the type, size, and extent of vitrification system testing necessary to select the HLW vitrification plant melter and confirm plant-scale system performance.

- Provide direction for D\&T of new or modified melter system process and design features, which may provide significant benefits relative to TWRS 1ife-cycle costs, ease of operation, system/component reliability, and overall system performance.

- Establish the type and extent of testing necessary to derive correlations between nonradioactive test simulants and actual HLW to validate projected performance of plant systems and products.

- Define HLW Program decision points, which allow for adjustments and refinements to the direction of vitrification system development activities and integration of test activity results with the balance-of-plant and process flowsheet studies.

- Establish testing activities and testing sequences within expected TWRS Program constraints, namely, cost, schedule, and technical risk.

Following approval of this testing strategy, a TWRS HLW melter system testing requirements document (WHC-SD-WM-RD-053 [CaImus 1995b]) was prepared 
for FY 1995 test activities and will be updated periodically in accordance with selected HLW Program decision-making activities. The document will define specific D\&T activities, expected test results, deliverables, and time phasing of key testing activities. The current HLW Program's baseline planning was established in April 1994 (RL 1994) and further delineated for FYs 1995 through 1997 in September 1994 (Jordan 1994). This baseline will be modified to implement the revised melter system testing strategy.

\subsection{MELTER D\&T STRATEGY}

This section discusses the strategies for the following areas: progression from small- to large-scale testing (phased testing approach), radioactive testing, integrated melter system testing using nonradioactive simulants, key related program decision points, and melter system testing costs.

\subsubsection{Phased Nonradioactive Testing Approach}

Historically, melter system D\&T activities have progressed from small- to large-scale tests, as successfully demonstrated at the SRS. For the Hanford Site HLW vitrification plant, this progression will proceed primarily from laboratory scale (crucible size, 100 to $200 \mathrm{~g}$ ) to bench scale ( 1 and $15 \mathrm{~kg} / \mathrm{h}$ ) to pilot scale $(15$ to $80 \mathrm{~kg} / \mathrm{h}$ ) to large scale (expected to be from $200 \mathrm{~kg} / \mathrm{h}$ to full scale). The Hanford Site HLW vitrification plant will require a glass production capacity between 400 and $800 \mathrm{~kg} / \mathrm{h}$.

Laboratory- and bench-scale testing generally focuses on materials or process chemistry and effects of changes in variables over a relatively wide range and is generally performed throughout the HLW Program. Pilot- and large-scale testing typically investigates scaleup considerations and identifies process- and equipment-related problems. Because the capital and operating costs escalate with an increase in size, large-scale tests are generally limited to verifying scaleup of laboratory-/bench-scale results for a limited number of conditions. These development stages are incorporated into the HLW Program melter development strategy for the baseline technologies using nonradioactive feed simulants.

The HLW melter testing program is separated into four testing phases. Phase I involves feasibility testing of the HTCM system technologies at laboratory and bench scale using an established blended DST/SST Hanford Site simulant waste feed composition. Phase II provide's for laboratory- and benchscale testing of a wider range of feeds and operating conditions. Melter feed compositions will be defined by retrieval and blending scenarios being developed for the Hanford Site. Phase III includes testing of pilot-scale systems with limited laboratory- and bench-scale testing as required. Phase III overlaps Phase II primarily because of the long lead time required to establish pilot-scale test capabilities. Phase IV focuses on testing required to resolve issues related to scaleup of the plant reference system for definitive plant design. Phase IV may include continued pilot- or largescale testing, depending on a program decision to be made during FY 1996 regarding the size of the system necessary to resolve high-risk technical issues. 
For all phases, existing test systems and equipment will be used when available and/or practical. For example, emphas is will be placed on operating the existing bench- and pilot-scale HTCM developed by PNL for the Hanford site. These systems will be operated to resolve'system feasibility issues generic to this and similar melter technologies. Melter systems at other locations may also warrant testing if significant benefits can be realized from alternate system designs. Vitrification system components and features (e.g., feed drying technologies and offgas systems) will be evaluated as part of the melter system assessment task. For components and features for which full-scale performance can be predicted from bench- and pilot-scale testing, an effort will be made to incorporate these features into integrated melter test systems. However, it is expected that large-scale integrated system testing will only be required if there are high-risk melter performance issues that must be resolved. If large-scale testing is necessary, individual component feature testing will be assessed for cost versus risk reduction on a case-by-case basis.

Figure 7-1 presents the general strategy for progressing from laboratoryto larger-scale testing to support the selection of the reference melter system for the plant. Figure $7-1$ also includes melter assessment activities and key decision-making activities. Results of the vitrification system D\&T activities will be coupled with planned engineering studies and melter system feature evaluations to provide the basis for periodic assessment of the HLW melters at key decision points. The activities to be performed in the testing phases are addressed in the following paragraphs and are discussed by the type of tests involved or the evaluations that will be performed.

\subsubsection{Phase I System Testing.}

- Laboratory - and bench-scale melters will be tested in FY 1995

(Phase I) for the high-temperature technologies, namely the HTCM and CCM technologies. These tests will be used to determine (1) the technologies to be carried forward for larger-scale testing and (2) the implementation strategy for pilot-scale integrated system design and system component testing.

- Evaluations will be performed on melter-specific and supporting equipment features for candidate technologies. These evaluations will include the performance of technical surveys; evaluating technical options; and providing recommendations relative to type of equipment, scale of testing, equipment operation, test facilities and configurations for implementation. The evaluations include a study of melter systems with features that offer significant benefits if developed and implemented. Viable options must have a high probability of being developed within TWRS Program constraints. Key features to be evaluated are melter feed drying technologies to improve waste processing capacity; alternate melter/offgas system designs to reduce offgas rate/volume, system size, and complexity; and alternate melter designs for mitigation of refractory sludge buildup within the melter cavity.

- Melter modeling capabilities for the joule-heated, ceramic-lined melter systems will be assessed. 


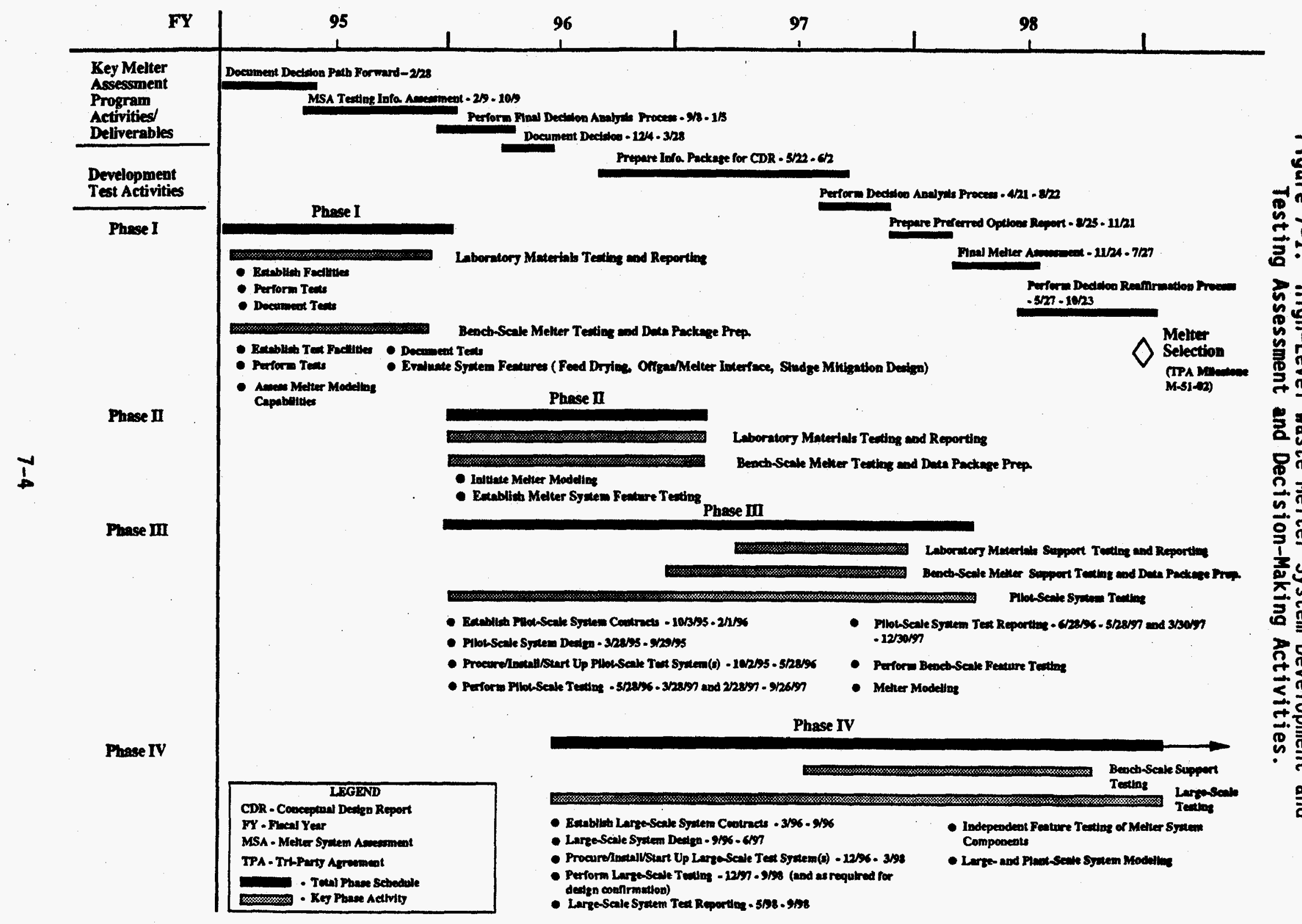




\subsubsection{Phase II System Testing.}

- Laboratory- and bench-scale testing will continue through Phase II to obtain process chemistry data for a wide range of potential Hanford Site feed types and to assess the performance of certain enhancement features (feed drying, alternative offgas systems/melter designs). This testing will al so provide support data for pilotscale tests and property data for melter modeling, primarily to define scaleup factors for prediction of plant-scale system performance.

- Modeling of the joule-heated, ceramic-lined melter systems will be initiated. This modeling will only be initiated if modeling capabilities are determined (in Phase I) to be adequately sophisticated to provide reasonable basis for assessing the performance of the large-scale system.

- Modeling of the CCM process will be initiated to provide information for larger-scale integrated system design and for characterizing the behavior and capacity of the CCM system. Modeling activities for the baseline HLW Program technologies will receive more emphasis in Phase III to correlate small-and large-scale test results and to provide the basis for more quantitative prediction of large- and/or plant-scale systems and components.

\subsubsection{Phase III System Testing.}

- Phase III testing activities will focus on testing of pilot-scale system(s), supporting systems, and associated melter components to resolve key equipment and process issues and to identify any new issues that may affect system performance and scaleup. Limited laboratory- and bench-scale testing will be performed to support pilot-scale testing and to further define composition limits for the candidate melter technologies. Current planning includes testing of two pilot-scale melter systems. The pilot-scale system for the HTCM technology will be PNL's operational HTCM test system. It is expected that a pilot- or large-scale system will be needed to evaluate CCM technology. In addition to PNL's HTCM system, other available, high-temperature, ceramic-lined system designs will be assessed and an alternate system tested, if necessary, to evaluate the impact of different designs on HTCM system performance.

\subsubsection{Phase IV System Testing.}

- Phase IV testing activities will focus on pilot- or large-scale system testing and independent feature testing to assess system operating and performance limits, confirm laboratory- and benchscale test data with process-limiting feed types, provide data for predicting plant operation and performance, confirm materials performance, provide data to establish predictions of plant-scale system performance, and identify any key issues associated with plant scaleup.

The planning basis assumes that only one large-scale system, the system selected as the reference plant melter system during 
Phase III, will be tested. The need for large-scale testing, specific system size and configuration, and type and duration of testing required will be determined based on the results of Phase II and III testing activities. If it is determined that large-scale testing is unnecessary to resolve key technical issues, or that resources are unavailable to support this scale of effort, pilotscale tests will be continued, as necessary, with existing or modified test equipment.

\subsubsection{Radioactive Testing}

The overall logic of the melter D\&T activities is to confirm that laboratory-, bench-, pilot-, and large-scale tests performed with nonradioactive HLW simulants can be used to predict the performance characteristics of the full-scale plant. Once this is demonstrated, the range of HLW feed compositions need only be tested on small scale to predict plant system performance. The validity of using information from nonradioactive simulant testing will be established by comparing the performance of laboratory- and bench-scale tests performed with pretreated radioactive waste to the same scale tests performed with nonradioactive simulants. Given these comparisons, small-scale tests with pretreated radioactive waste can then be extrapolated with reasonable confidence to the full-scale HLW vitrification plant.

Testing with radioactive feeds is performed on small scale primarily because such tests are extremely expensive and require extensive facility support. Laboratory- and bench-scale radioactive testing of baseline TWRS HLW melter system technologies with Hanford Site HLW feed is expected to yield good correlation to plant-scale system performance, relative to process chemistry, melting, and product performance behavior. In addition, this testing will highight differences between simulants and actual waste process and product performance, which may lead to refinement of nonradioactive feed simulants for large-scale testing.

The expectation that reasonable correlations will be established for the HLW baseline technologies is based on experience with laboratory- and benchscale $(1 \mathrm{~kg} / \mathrm{h})$ tests with radioactive HLW feeds and pilot-scale tests with nonradioactive simulants performed in support of the DWPF and HWVP projects. The TWRS HLW D\&T strategy is to conduct laboratory- and bench-scale melter system tests with pretreated radioactive tank waste. These results will be correlated with simulant tests performed at the same scale using similar test systems. The specific melter size required for bench-scale testing will be determined after the reference HLW vitrification plant melter system is selected in FY 1997. However, scoping studies that evaluate bench-scale testing needs and possible options for scale system tests will be estimated starting in FY 1995. These studies will support the development of an integrated testing strategy and a facility planning strategy for radioactive wastes. Sizing of the bench-scale system will primarily depend on tank sampling and retrieval capabilities, results of laboratory-scale tests with simulants, perceived impact of technical issues, radioactive facility availability, and cost/schedule impacts.

Radioactive pilot- or larger-scale system or component tests should not be necessary for the prediction of system performance capabilities, or to confirm glass property models and glass product performance characteristics. 
Once it is established that the nonradioactive simulant is representative of actual tank waste at crucible and bench scale, scaling factors and overall plant system performance could be predicted from large-scale simulant tests. Plans have not been made to accommodate pilot-scale radioactive system testing for the plant reference melter technology. If testing of this scale is determined to be necessary, a radioactive melter system (including remote operating features and feed availability) would most likely be unavailable until after the scheduled plant detailed design is completed.

\subsection{REFERENCE MELTER SELECTION}

Selection of the HLW vitrification plant melter technology and key system features is scheduled for September 1998 (Tri-Party Agreement Milestone M-51-02). Two interim decision points are identified in the new HLW baseline program to allow for adjustments to melter system testing activities. These decision points were established to ensure that sufficient information is available to select an HLW vitrification plant melter system and meet the Tri-Party Agreement commitment. To ensure that the data required for key program decisions are available when needed, the melter testing activities outlined in the previous section have. been fully integrated with the HLW melter selection strategy.

The first decision point is at the end of calendar year 1995. At that time, FY 1995 melter system D\&T results will be assessed to determine whether testing of candidate HTCM system technologies should continue as scheduled, be eliminated, or be redirected. A determination will be made regarding overall feasibility and probability of successful development of high-temperature technologies within expected TWRS Program constraints. Melter system assessment and decision-making activities are presented in Figure 7-1. If either, or both, high-temperature technologies are determined to have unacceptable risk, the resource allocation will shift from development of high-temperature technologies to development and engineering testing of lower temperature technologies. The decision will consider extent of laboratory-, bench-, or pilot-scale integrated melter system testing needed to resolve key performance and design issues.

At the second decision point, which is in mid-FY 1997, small(1aboratory- and bench-scale) and large- (pilot-scale, integrated pilot-scale, and pilot- and large-scale system features) scale test resuits will be assessed to determine. which technology is best suited to be the primary and backup plant melter system technology. Taken into consideration will be the need to continue pilot-scale testing of the primary and backup technologies and for large-scale testing of the primary reference technology to support conceptual and definitive plant design. The configuration needed for melter system testing of radioactive wastes will be determined at the mid-FY 1997 decision point corresponding to selection of the preferred reference plant vitrification system. Detailed planning and implementation of radioactive bench-scale test system design, procurement, installation, and operation will be initiated after the FY 1997 decision and will be coordinated with other TWRS Program element (e.g., retrieval and pretreatment) activities. 


\subsection{MELTER SYSTEM D\&T COSTS}

The estimated costs for implementing this melter development, testing, and evaluation strategy are shown in Table 7-1. The table shows WHC and PNL costs for the melter activities leading up to reference melter selection. It does not include the costs for glass formulation, feed/process chemistry, and engineering activities that indirectly support the melter development effort. The costs for FY 1995 are from a recently submitted change request to WHC-SP-1101, Tank Waste Remediation System Multi-Year Work Plan (Jordan 1994). Because the detailed work planning for FYs 1996 to 1998 has not yet been revised to implement this strategy, the costs for those years should be considered preliminary estimates. 
Table 7-1. Estimated Melter Development Costs (dollars in thousands).

\begin{tabular}{|c|c|c|c|c|}
\hline Development activity & FY 1995 & FY 1996 & FY 1997 & FY 1998 \\
\hline \multicolumn{5}{|l|}{ Phase 1} \\
\hline Laboratory Material Tests & $1,025^{1}$ & o & 0 & 0 \\
\hline Bench-Scale Melter Tests & $4,075^{2}$ & 0 & 0 & 0 \\
\hline \multicolumn{5}{|l|}{ Phase II } \\
\hline Laboratory Material Tests & 0 & $1,370^{3}$ & 0 & 0 \\
\hline Bench-Scale Helter Tests & 0 & $2,100^{4}$ & 0 & 0 \\
\hline \multicolumn{5}{|l|}{ Phase III } \\
\hline Laboratory Material Tests & 0 & 0 & 600 & $\mathbf{0}$ \\
\hline Bench-Scale Melter rests & 0 & 0 & 850 & 0 \\
\hline Pilot-Scale Melter Design & 1,227 & 0 & 0 & 0 \\
\hline Pilot-Scale Melter Tests & 0 & $4,930^{5}$ & $5,700^{6}$ & $2,200^{7}$ \\
\hline \multicolumn{5}{|l|}{ Phase IV } \\
\hline Bench-scale Melter Tests & 0 & 0 & 850 & 1,600 \\
\hline Large-Scale Testing & 0 & $1,700^{8}$ & $2,000^{9}$ & $5,000^{10}$ \\
\hline Radioactive Testing & 188 & 600 & 1,050 & $3,550^{11}$ \\
\hline Melter Assessment/Selection ${ }^{12}$ & 1,463 & 764 & 692 & 710 \\
\hline Total & 7,978 & 11.464 & 11.742 & 13,060 \\
\hline
\end{tabular}

NOTE: These estimates do not include any glass formulation and feed/process chemistry efforts needed to support melter testing activities.

1 In addition to material testing, this includes $\$ 140,000$ for independent feature testing.

2This includes $\$ 987,000$ carryover to complete stirred melter installation, two high-temperature melter ${ }_{3}$ bench scale-runs and two cold-crucible melter bench-scale runs.

3 In addition to material testing, this includes some independent feature testing.

4Th includes four 10-day bench-scale tests.

This includes procurement of one pilot-scale melter (or pilot-scale special feature testing) and one pifot-scale test run.

Two pilot-scale test runs.

One pilot-scale run.

8 This includes design and procurement of long-lead items for one large-scale melter.

9his includes completion of procurement for the large-scale melter.

10 This includes completion of construction, startup, and one large-scale melter test run.

11 In addition to laboratory-scale radioactive testing, this includes $\$ 2$ million for radioactive benchigcale melter design.

Includes Pacific Northwest Laboratory melter performance assessment, Westinghouse Hanford Company melter evaluation, and Westinghouse Hanford Company melter selection activities. 
WHC-EP-0847

This page intentionally left blank. 


\subsection{REFERENCES}

Calmus, R. B., 1995a, Tank Waste Remediation System High-Level Vitrification System Development and Testing Strategy, WHC-SD-WM-SD-007, Rev. 0, Westinghouse Hanford Company, Richland, Washington.

Calmus, R. B., 1995b, Tank Waste Remediation System High-Level Waste Vitrification System Development and Test Requirements, WHC-SD-WM-RD-053, Rev. 0, Westinghouse Hanford Company, Richland, Washington.

Ecology, EPA, and DOE, 1994, Hanford Federal Facility Agreement and Consent Order, as amended, Washington State Department of Ecology, U.S. Environmental Protection Agency, and U.S. Department of Energy, Olympia, Washington.

Jordan, K. N., 1994, Tank Waste Remediation System Multi-Year Work Plan, WHC-SP-1101, Westinghouse Hanford Company, Richland, Washington.

RL, 1994, Tank Waste Remediation System Program Implementation Plan, DOE/RL-92-58, U.S. Department of Energy, Richland Operations Office, Richl and, Washington. 
WHC-EP-0847

This page intentionally left blank. 


\subsection{GLOSSARY}

\section{ABBREVIATIONS AND ACRONYMS}

CCM cold-crucible melter

D\&T

development and testing

DOE

DWPF

FY

HLW

HTCM

HWVP

LTCM

MSWG

PNL

RL

SRS

TAC

TRS

TTAG

TWRS

WHC

U.S. Department of Energy

Defense Waste Processing Facility

fiscal year

high-level waste

high-temperature, ceramic- 1 ined melter

Hanford Waste Vitrification Plant

low-temperature, ceramic-lined melter

Melter Selection Working Group

Pacific Northwest Laboratory

U.S. Department of Energy, Richland Operations Office Savannah River Site

Technical Advisory Committee

Technical Resource Staff

TWRS Technical Assessment Group

Tank Waste Remediation System

Westinghouse Hanford Company 


\section{WHC-EP-0847}

This page intentionally left blank.

GL-2 
WHC-EP-0847

APPENDIX A

MEETING PARTICIPANTS

A-1 
WHC-EP-0847

This page intentionally left blank. 
WHC-EP-0847

APPENDIX A

MEETING PARTICIPANTS

A listing of meeting participants and a brief summary of their experience, specialties, and affiliations follows.

Technical Advisory Committee

- Frank E. Woolley, Technical Advisory Committee Chairman

Corning* International, Incorporated

Dr. Woolley is Manager of Research in the Melting Technology section of Corporate Engineering at Corning Incorporated. His group investigates the fundamental processes in glass melting and develops new industrial melting processes for Corning's domestic and international glass melting.

- L. David Pye, New York State College of Ceramics

Dr. Pye is a professor of Glass Science at the New York State College of Glass Ceramics, Director of the Institute of Glass Science and Engineering, and Director of the National Science Foundation's Industry-University Center for Glass Science. He is an internationally renowned glass chemist with specific expertise in nuclear waste glasses.

- Eric Brown, British Nuclear Fuels Ltd.

Mr. Brown has 13 years of lead experience in design, installation, startup, operation, and decommissioning relative to the British high-level waste (HLW) vitrification plant in Sellafield, England. The Sellafield Plant uses the French-designed, low-frequency, induction-heated, metal-can melter system technology. Mr. Brown has specific expertise in the design, operation, and maintenance of the melter system and melter support system components.

- Joseph A. Gentilucci, JAG Tech. Services, Incorporated

Mr. Gentilucci is a private consultant who is retired after working 16 years on various aspects of the design, construction, and startup testing of the Savannah River Site's (SRS) HLW Defense Waste Processing Facility (DWPF). In his last position of Manager of Process Engineering, Mr. Gentilucci was responsible for maintaining overall technology assurance and configuration of the process including directing technical experimental programs required to support operations.

*Corning is a trademark of Corning Glass Works. 
- Steven M. Barnes, West Valley Nuclear Services

Mr. Barnes has managed the integrated process system testing activities at the U.S. Department of Energy's (DOE) West Valley Demonstration Project (WVDP) HLW vitrification plant in West Valley, New York. He also has specific experience in the design and development of the WVDP melter technology and waste form qualification activities.

\section{Tank Waste Remediation System (TWRS) Technical Staff}

- Roger W. Powell

Dr. Powell is the TWRS HLW Project Office Manager. His experience includes 20-plus years in nuclear materials development.

- Gary E. Stegen

Mr. Stegen is a principal engineer in the TWRS Vitrification Development group with 20 years of experience, including 8 years of process engineering for the Hanford Waste Vitrification Plant (HWVP) Project and 8 years in chemical process research and development.

- James R. Baker

For the last 7 years, Mr. Baker has been involved in HLW vitrification plant process design with the HWVP Project.

- Robert A. Watrous

$\mathrm{Mr}$. Watrous has 34 years of experience in reactor fuels preparation, fuels separations processing, and HLW disposal technology development at both the DOE Hanford and Oak Ridge Sites. This includes 7 years of experience with the HWVP Project.

- Ronald B. Calmus

Mr. Calmus has 4 years of experience in nuclear plant materials performance engineering and plant engineering/operations, 2 years of experience in research and development of nuclear materials, and 4 years of experience in $H L W$ vitrification system development and testing with the HWVP Project.

- George P. Janicek

Mr. Janicek has 30-plus years of experience in the nuclear field, including 11 years in design and development of remote handling and facility systems and 5 years in HWVP operations and maintenance engineering design. 


\section{Technical Resource Staff}

- Dennis F. Bickford, Westinghouse Savannah River Company

Mr. Bickford has lead responsibility for identifying and developing new nuclear waste vitrification process technologies for the DOE SRS. Also, he has specific expertise in the DWPF melter technology and DWPF alternative vitrification system technologies that are being considered for processing SRS HLW.

- Christopher C. Chapman, Pacific Northwest Laboratory (PNL)

Mr. Chapman has lead responsibility for melter system development for PNL and was a primary developer of the joule-heated, ceramiclined melter technology that is the baseline HLW vitrification technology for most of the world, including the United States (WVDP/DWPF/HWVP), Japan, and Europe (excluding France and England).

- Wolfgang Grunewald, Kernforschungszentrum, Karlsruhe GmbH

Mr. Grunewald is a primary developer of the German-designed, jouleheated melter systems, with significant experience in testing and operating these systems and a broad knowledge of international HLW vitrification system development activities.

- Bruce A. Higley, Westinghouse Hanford Company

Mr. Higley is considered a Hanford Site cognizant engineer on cyclone-combustion melting technology and is knowledgeable on recent consideration of this type of technology for vitrification of HLW.

- Antoine Jouan, French Atomic Energy Commission (CEA Marcoule)

Mr. Jouan has lead responsibility for development of the Frenchdesigned, high-frequency induction melter technology (cold-crucible melter technology). He has in-depth knowledge of the commercial HLW low-frequency, induction-melter technology employed in England and France relative to system development, design, and operation.

- Gunther Roth, Kernforschungszentrum, Karlsruhe GmbH

Dr. Roth is a primary developer of the German-designed, joule-heated melter systems with significant experience in testing and operating these systems and a broad knowledge of international HLW vitrification system development activities.

- Jeffrey E. Surma, PNL

Mr. Surma is one of the Hanford Site's foremost experts on plasma and plasma-arc melter technologies relative to design, development, testing, and operation of this technology for commercial applications. 
The following Hanford Site staff provided key support:

John Fabian, Westinghouse Hanford Company, meeting facilitator

Valeria Hunter, Pacific Northwest Laboratory, meeting facilitator

Mike Elliott, Pacific Northwest Laboratory, lead Hanford Site technical staff; responsible for preparation of melter assessment technical information

Phyllis Shafer, Pacific Northwest Laboratory, Hanford Site technical staff; responsible for preparation of melter assessment technical information. 
WHC-EP-0847

APPENDIX B

TANK MASTE REMEDIATION SYSTEM DECISION

BOARD MEMBERS AND STAKEHOLDER GROUPS

B-1 
WHC-EP-0847

This page intentionally left blank. 
WHC-EP-0847

APPENDIX B

TANK WASTE REMEDIATION SYSTEM DECISION

BOARD MEMBERS AND STAKEHOLDER GROUPS

Members of the Tank Waste Remediation System (TWRS) Decision Board are listed with their respective titles at the time of the assessment.

- Dr. Walter J. Apley (Pacific Northwest Laboratory), Director of TWRS Technology Development Program

- Dr. Leonard F. Ermold (Westinghouse Hanford Company [WHC]), Director of TWRS Engineering

- James 0. Honeyman (Director of Disposal Programs, TWRS

- Michael A. Siano (WHC), Director of Construction Projects. below:

The participating stakeholder groups and their representatives are listed

- Oregon Department of Energy

Dirk Dunning, Principal Engineer, Hanford Site Programs Coordinator

- Yakama Indian Nation, Environmental Restoration/Waste Management

F. Robert Cook, Technical Analyst

- Washington State Department of Ecology

John H. Gratham, Nuclear Waste Program

Robert E. Cordts, Nuclear Waste Program

- U.S. Department of Energy, Richland Operations Office

Madan Dev, Tank Waste Retrieval, Treatment, and Immobilization Division

Neil R. Brown, Tank Waste Retrieval, Treatment, and Immobilization Division

Steven T. Burnum, Technology Program Manager, Tank Waste Retrieval, Treatment, and Immobilization Division 
WHC-EP-0847

This page intentionally left blank. 
WHC-EP-0847

APPENDIX C

CANDIDATE MELTER TECHNOLOGIES

C-1 
WHC-EP-0847

\section{ACKNONLEDGNENTS}

This report was prepared by P. J. Shafer and M. L. Elliott of Pacific Northwest Laboratory, Richland, Washington. 


\section{CONTENTS}

C1.0 JOULE-HEATED MELTERS .................... C-5

C1.1 LOW-TEMPERATURE, JOULE-HEATED MELTERS . . . . . . . . C-5

C1.1.1 Low-Temperature, Ceramic-Lined, Joule-Heated

Melters ............. C-6

C1.2 LOW-TEMPERATURE, METAL-LINED, STIRRED, JOULE-HEATED

MELTERS . . . . . . . . . C C 6

C1.3 HIGH-TEMPERATURE, JOULE-HEATED MELTERS . . . . . . . . c-6

C1.3.1 High-Temperature, Ceramic-Lined, Joule-Heated

Melters . . . . . . . . . . C-8

C1.3.2 High-Temperature, Metal-Lined, Joule-Heated

C1.3.3 High-Temperature, Metal-Lined, $\dot{C} 0 \dot{1 d-W a l i, ~ j o u l e-~}$

Heated Melter .............. C-9

C2.0 COMBUSTION MELTERS . . . . . . . . . . . . . . . C-9

C2.1 CONVENTIONAL COMBUSTION MELTERS . . . . . . . . . . . C-9

C2.2. CYCLONE COMBUSTION MELTERS ............... . C-11

C3.0 INDUCTION MELTERS ..................... C-12

C3.1 LOW-FREQUENCY INDUCTION MELTERS ..............

C3.2 HIGH-FREQUENCY INDUCTION MELTERS ...............

C4.0 PLASMA/ARC FURNACES .................... C-13

C4.1 PLASMA TORCHES ................. . . C-13

C4.2 TRANSFERRED PLASMA ARC MELTERS .............. C-14

C4.3 ARC FURNACES ................... C-14

C5.0 MICROWAVE MELTERS .................... C-14

C6.0 ROTARY KILNS ....................... . . . . . . . . .

C7.O HOT ISOSTATIC PRESSING .................... . . . . . .

C8.0 IN-CAN MELTER ....................... C-15

C9.0 REFERENCES . . . . . . . . . . . . . . . . . C-16

C10.0 GLOSSARY ....................... . . . . . . . . . . . 
WHC-EP-0847

\section{LIST OF FIGURES}

C-1 Low-Temperature, Joule-Heated Melter . . . . . . . . . . . . C-7

C-2 Stirred Melter.................. C-7

C-3 High-Temperature, Joule-Heated Melter ........... C-8

C-4 Conventional Fuel-fired Melter . . . . . . . . . C-10

C-5 Cyclone Combustion Melter ................11

C-6 Cyclone Combustion Melter .............. C-13 
WHC-EP-0847

APPENDIX C

\section{CANDIDATE MELTER TECHNOLOGIES}

This appendix provides a brief description of the various groups and subgroups of melters initially considered as candidates for the Hanford Site high-level waste (HLW) vitrification plant during the June meeting of the Melter Selection Working Group (MSWG). After the MSWG down-selected the group to six, detailed data packages were compiled for the second (August) MSWG meeting. These data packages are being released as a separate Tank Waste Remediation System document. The primary grouping was made based on the energy source for the melters: joule heating, combustion, induction, etc. The subgroupings are different for each primary group because of the diversity within the various groups.

\section{C1.0 JOULE-HEATED MELTERS}

Joule-heated melters, also referred to as electric melters, are heated by passing alternating electric current through glass via submersed electrodes. The alternating current is conducted between two or more electrodes by mobile ions in the molten glass. The resistance of the glass produces a heatgenerating effect known as joule heating. Electric melters in the commercial glass industry are either all-electric or electric-boosted. Electric-boosted melters have energy supplied by joule heating of the glass as well as from torches above the glass batch. The advantages of electric melting are that it reduces volatilization of the melt constituents, reduces the offgas system requirements, and allows melting of black glasses where radiant heat transfer is 7 imited. The temperature limit of a joule-heated melter is determined by the materials of construction for the refractory and electrodes. Most jouleheated melters are ceramic lined, but a few are metal 1 ined. The metal melters either operate at a low temperature $\left(<1200^{\circ} \mathrm{C}\right)$, or are water cooled in such a way that the metal liner is protected by a frozen layer of glass. The electrodes in a joule-heated melter can be inserted into the glass from the top, sides, or bottom of the melter. Because glass is not conductive at room temperature, joule-heated melters must have auxiliary heating for initial startup. This is usually provided by electrical resistance heaters or torches placed in the plenum space above the glass surface. Other startup methods sometimes used include laying conductive starter paths between the electrodes and using microwave heat sources.

\section{C1.1 LOW-TEMPERATURE, JOULE-HEATED MELTERS}

Low-temperature, joule-heated melters, as classified herein, are melters whose maximum operating temperature is below $1200^{\circ} \mathrm{C}$. These melters usually use electrode materjals whose melting points do not allow high-temperature operation. Inconet 690 , a high-chromium nickel alloy, is the electrode

"Inconel is a trademark of INCO Alloys International, Inc. 
material most often used for low-temperature waste melters because of its resistance to corrosion.

\section{C1.1.1 Low-Temperature, Ceramic-Lined, Joule-Heated Melters}

The ceramic-lined, joule-heated melter has been selected for HLW vitrification in the United States (at the Savannah River Site and West Valley Demonstration Project), Germany, Japan, and Russia. These melters have two or more layers of refractory inside a water-cooled containment box (see Figure $(-1)$. In some cases, the shell is not water cooled. The glasscontacting refractory is usually a high-chromia, fusion-cast ceramic (either Carborundum K-3 or a chrome alumina zirconia silica [AZS]). This is a particular area of deviation from melters used in the commercial glass industry, in which high-chrome refractories are avoided except in high-wear areas (e.g., throat blocks) because of the strong coloring effect of chrome. One exception to this is the fiberglass industry. The HLW melters are able to use the chrome refractories throughout the melter because the color of the product glass is not important. At 1050 to $1150^{\circ} \mathrm{C}$, reported corrosion rates for Carborundum $\mathrm{K}-3$ were 10 to $20 \mu \mathrm{m} /$ day in the most aggressive areas of other melters and 4 to $8 \mu \mathrm{m} /$ day on the pilot-scale ceramic melter at Pacific Northwest Laboratory (Larson 1989). The electrical conductivity of glasscontacting refractory is important in joule-heated melters. If the refractory is too conductive (i.e., the chrome content is too high), it is possible that a short circuit will occur between the electrodes via the refractory. This is a concern only with low-conductivity glasses. Because the fused-cast refractory is not very insulative, it is usually backed with layers of more insulative ceramics such as high-alumina castable ceramics and ceramic board.

\section{C1.2 LOW-TEMPERATURE, METAL-LINED, STIRRED, JOULE-HEATED MELTERS}

The use of metal-1ined, joule-heated melters has been limited. Stir-Melter, Inc. has introduced the WV series of Stir-Melters that use Inconel 690 in all glass-contacting areas (see Figure $\mathrm{C}-2$ ), including an Inconel impeller that is used to mechanically agitate the melter, giving rise to its name. The use of this material limits the operating temperature to $1100^{\circ} \mathrm{C}$. The glass is heated by passing alternating electric current between the agitator and the tank walls. Auxiliary heaters are provided for startup.

\section{C1.3 HIGH-TEMPERATURE, JOULE-HEATED MELTERS}

High-temperature, joule-heated melters, as classified herein, are melters whose maximum operating temperature is above $1200^{\circ} \mathrm{C}$. Most commercial electric melters fall into this category. The main difference between lowtemperature and high-temperature electric melters is the electrode materials of construction. Electrode materials of construction for melters above $1200{ }^{\circ} \mathrm{C}$ include molybdenum, graphite, tin oxide, platinum, iron, and other metals and metal oxides. Molybdenum electrodes are used in most commercial electric melters except for those making glasses that contain oxidizing species such as lead and arsenic. This may be a problem for the Hanford Site

"Stir-Melter is a trademark of Stir-Melter, Inc. 
Figure C-1. Low-Temperature, Joule-Heated Melter.

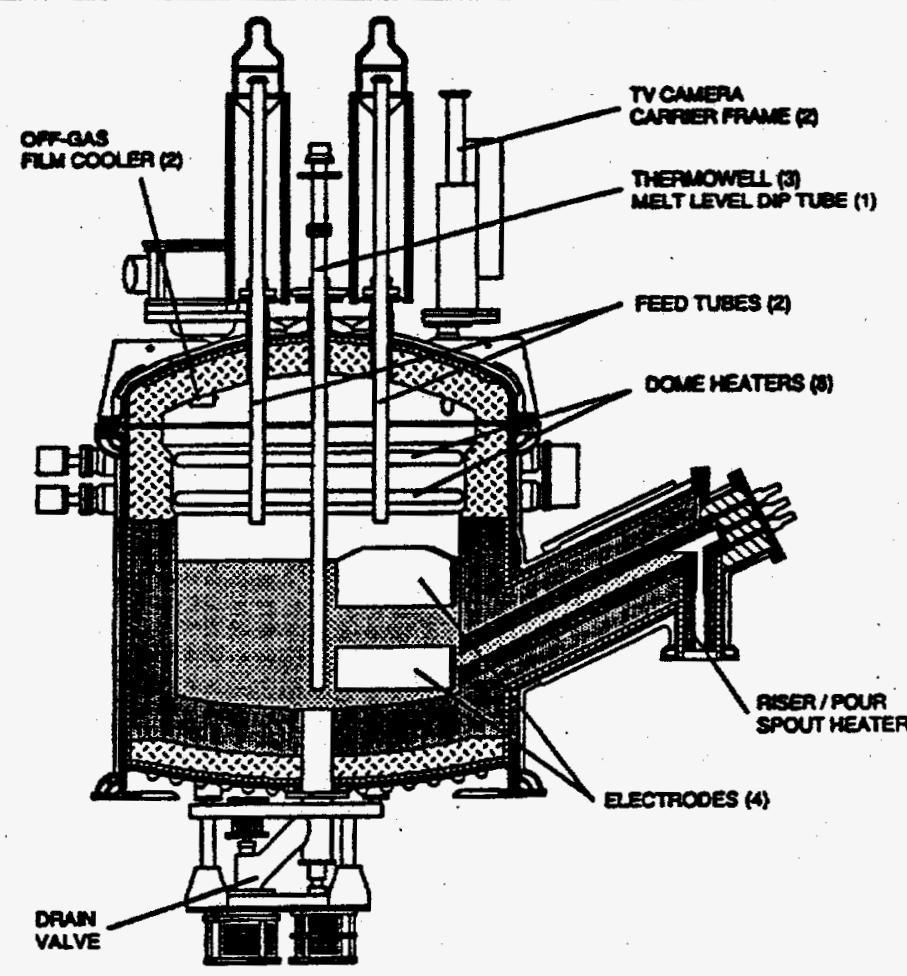

Figure C-2. Stirred Melter.

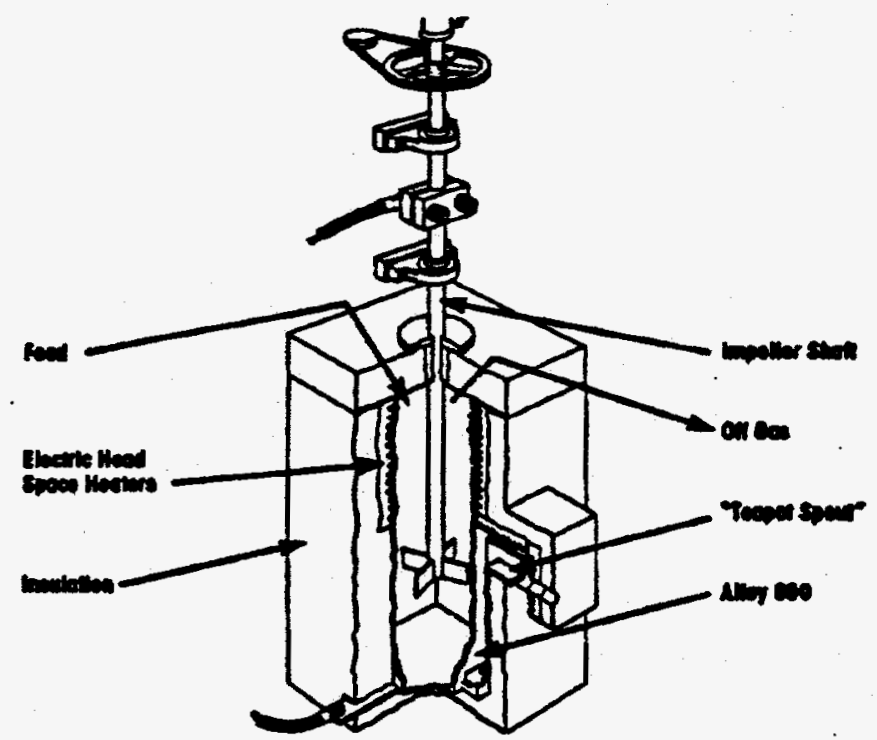


melter because the reference glass contains several metal oxides that are above molybdenum on the electrochemical series. Molybdenum electrode stems must be either cooled or sealed from the atmosphere because molybdenum rapidly oxidizes in air above $600{ }^{\circ} \mathrm{C}$. Several electrode holders have been designed to protect molybdenum electrodes from air oxidation. Tin oxide does not have the oxidation problems of molybdenum, but it does have other problems. Tin oxide electrodes must be larger than molybdenum electrodes because the maximum current density is lower $\left(0.5 \mathrm{~A} / \mathrm{cm}^{2}\right.$ versus $2 \mathrm{~A} / \mathrm{cm}^{2}$ for molybdenum). This causes a problem because tin oxide is difficult to manufacture, and available sizes are very limited. Tin oxide also has a low tensile strength, which makes the feeding of electrodes difficult. Graphite is limited by its low allowable current density $\left(0.2 \mathrm{~A} / \mathrm{cm}^{2}\right)$ and its incompatibility with oxidizing glasses. Platinum electrodes degrade in reducing glasses.

\section{C1.3.1 High-Temperature, Ceramic-Lined, Joule-Heated Melters}

Ceramic-lined electric melters are very similar to their low-temperature counterparts (see Figure $\mathrm{C}-3$ ). The refractories for waste melters will be the same high-chrome ceramics. The only difference will be the expected lifetime of the refractories. It has been reported that refractory corrosion rates double for every 50 to $100^{\circ} \mathrm{C}$ of temperature increase (Engineered Materials Handbook, vol. 4, Ceramics and Glasses, p. 388, "Melting/Fining" [Woolley 1991]), but this correlation is for the same glass composition and cannot be used when changing to a harder (higher viscosity) glass. Corrosion tests for Carborundum $\mathrm{K}-3$ are being conducted for HLW glass simulants at high

temperatures. The corrosion rate for this material is not assumed to be a problem, considering the fact that commercial glass melters operating at $1500{ }^{\circ} \mathrm{C}$ can operate for 2 to 10 years between rebuilds using AZS refractories.

Figure C-3. High-Temperature, Joule-Heated Melter.

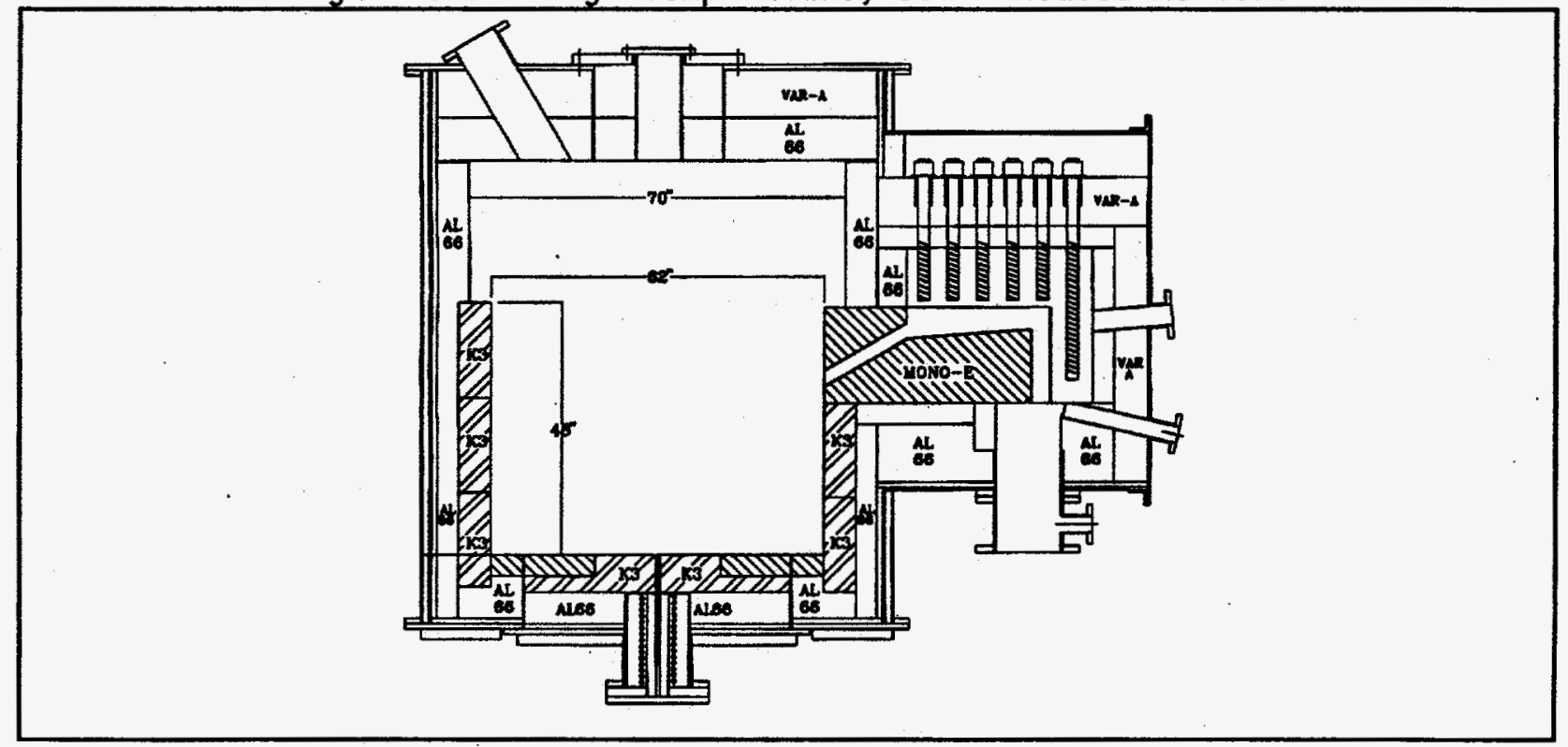




\section{C1.3.2 High-Temperature, Metal-Lined, Joule-Heated Melters (Hot Mall)}

The use of metal-lined, high-temperature electric melters has been limited. Corning has designed a molybdenum-lined decogonal furnace for producing high-quality borosilicate glasses at high specific. melting rates (Trier 1987). The Corning melter had three top-entering molybdenum electrodes that allowed operation at $1700{ }^{\circ} \mathrm{C}$.

\section{C1.3.3 High-Temperature, Metal-Lined, Cold-Wall, Joule-Heated Melter}

The cold-wall, high-temperature, joule-heated melter is similar to the hot-wall metal melter except that the metal pot is cooled. This results in the formation of a protective layer of glass on the outside wall. The protective layer reduces the corrosion of the pot's materials and allows the bulk of the melter to be run at high temperatures. The electrodes can be either top, side, or bottom entering and are constructed out of the same materials as the other high-temperature, joule-heated melters. The Pochet melter is one example of this type of melter (Engineered Materials Handbook, vol. 4, Ceramics and Glasses, p. 404, "Fiberglass" [Tooley 1991]). It is used to produce fiberglass at capacities up to 20 tons/day. One of the difficulties with this type of design is removing the glass from the melter. The Pochet melter uses a bottom drain tube with a top-entering glass flow control rod. Another cold-wall melter with a proprietary bottom drain has been proposed. This drain has not been tested to date. Temperature control with these melters is also an issue because of the fine balance between coolant supply, frozen glass thickness, and electrode spacing.

\section{C2.0 COMBUSTION MELTERS}

Combustion or fuel-fired melters supply energy to the glass batch by direct or indirect contact with combustion flames. The traditional fuel sources have included coal, oil, and natural gas. Presently, natural gas is the principal fuel for glass melting in the United States. Coal is seldom, if ever, used and oil is mainly used as a backup fuel (Tooley 1974). As mentioned earlier, some melters have both combustion heating from the top surface and electric boosting from within the melt. These melters are sometimes referred to as electrically-boosted melters or mixed melters.

\section{C2.1 CONVENTIONAL CONBUSTION MELTERS}

Conventional combustion melters supply energy to the glass by directing a flame over the top of the melt surface (see Figure C-4). These melters rely on heat transfer (mainly radiation and natural convection) from the top glass surface for heating of the bulk of the glass. Usually, dry feed is introduced at one end of the melter where it forms a batch blanket that is slowly melted.

\footnotetext{
"Corning is a trademark of Corning Glass Works.
} 
Figure C-4. Conventional Fuel-Fired Melter.

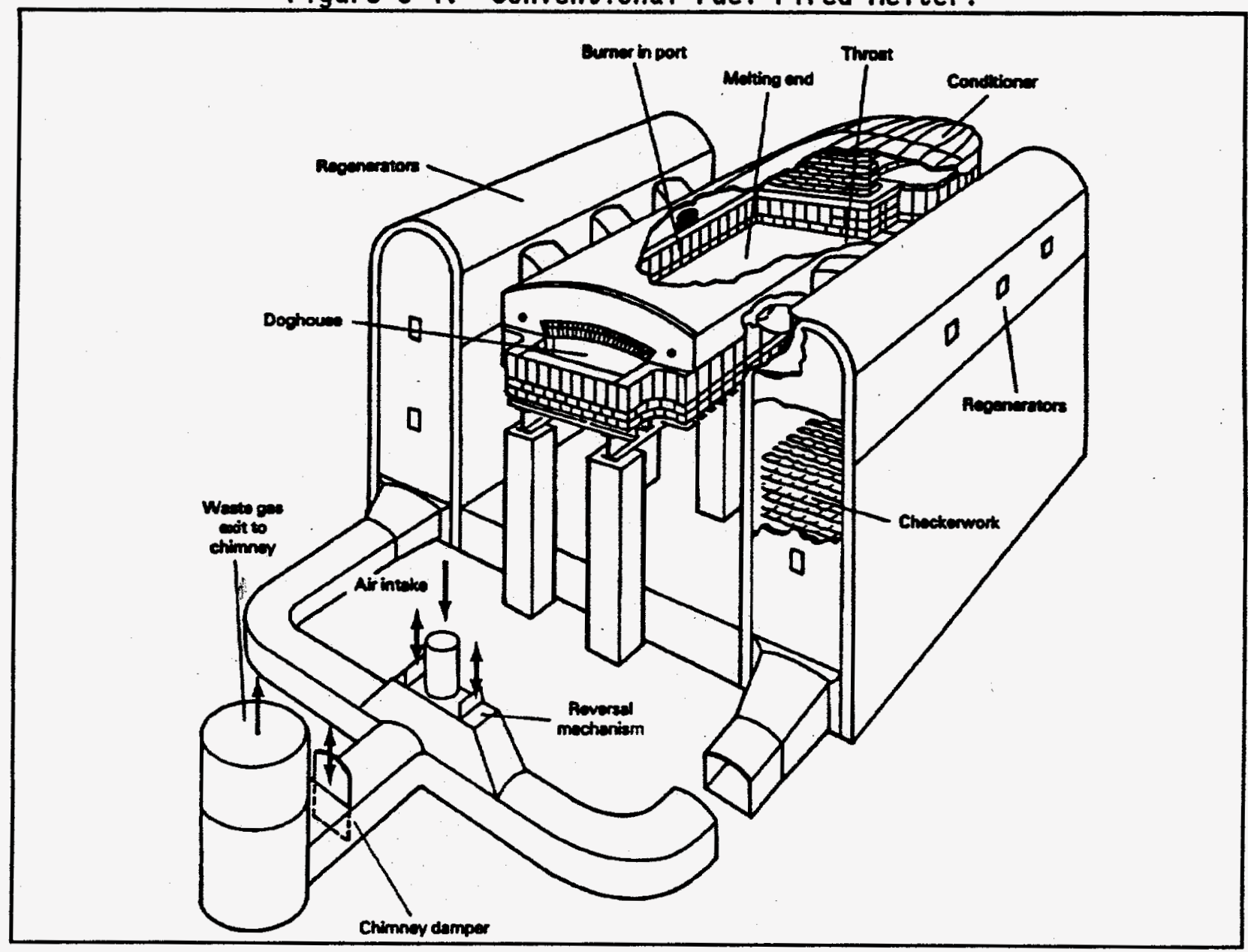

From here, the glass flows into an area for fining (removal of bubbles). This area is not covered by batch material because convection currents with in the tank keep the batch blanket near the front wall. Finally, the glass flows into a separate section (the forehearth) for further homogenizing and cooling in preparation for forming. Some melters employ mechanical agjtators in the forehearth to aid in homogenizing.

There are three main types of combustion melters: regenerative, recuperative, and direct-fired. The first two types use the hot flue gas to preheat the combustion air before mixing with the fuel. This reduces the overall energy consumption by 50 to $70 \%$ (Engineered Materials Handbook, vol. 4, Ceramics and Glasses, p. 390, "Melting/Fining" [Woolley 1991]). The only difference between these two types of melters is the method of heat exchange. Direct-fired combustion melters do not recover heat from the flue gas. The inefficiency of a direct-fired fuel melter is balanced by the reduced capital and maintenance costs associated with regenerators and recuperators.

Commercial combustion melters (as well as commercial electric melters) generally use fusion-cast AZS for the glass-contacting refractories. As mentioned earlier, high-chrome refractories are avoided in the commercial 
glass industry except in high-wear areas (e.g., throat blocks) because of the strong coloring effect of chrome. The HLW melters.will be able to use the more durable chrome refractories (e.g., Carborundum K-3 or chrome AZS)

throughout the melter because the color of the product glass is not important.

\section{C2.2 CYCLONE COMBUSTION MELTERS}

Cyclone combustion melters increase heat transfer over conventional combustion melters by directly contacting the incoming batch with the hot combustion gases. The preheated air and fuel are introduced tangentially into a cyclone where combustion takes place. The fuel can be coal, oil, or natural gas. The combustion chamber can be either cylindrical or conical. The batch materials are introduced into the combustion chamber in such a way that they are suspended in the cyclone and melted in the hot combustion gases. The heavier molten glass agglomerates fall out of the bottom of the cyclone into a receiving basin or soak tank. This concept was introduced in a paper by Alexander Ferguson in 1923 (Pincus 1980). Variations of this technology are currently proposed (see Figure C-5).

Figure C-5. Cyclone Combustion Melter.

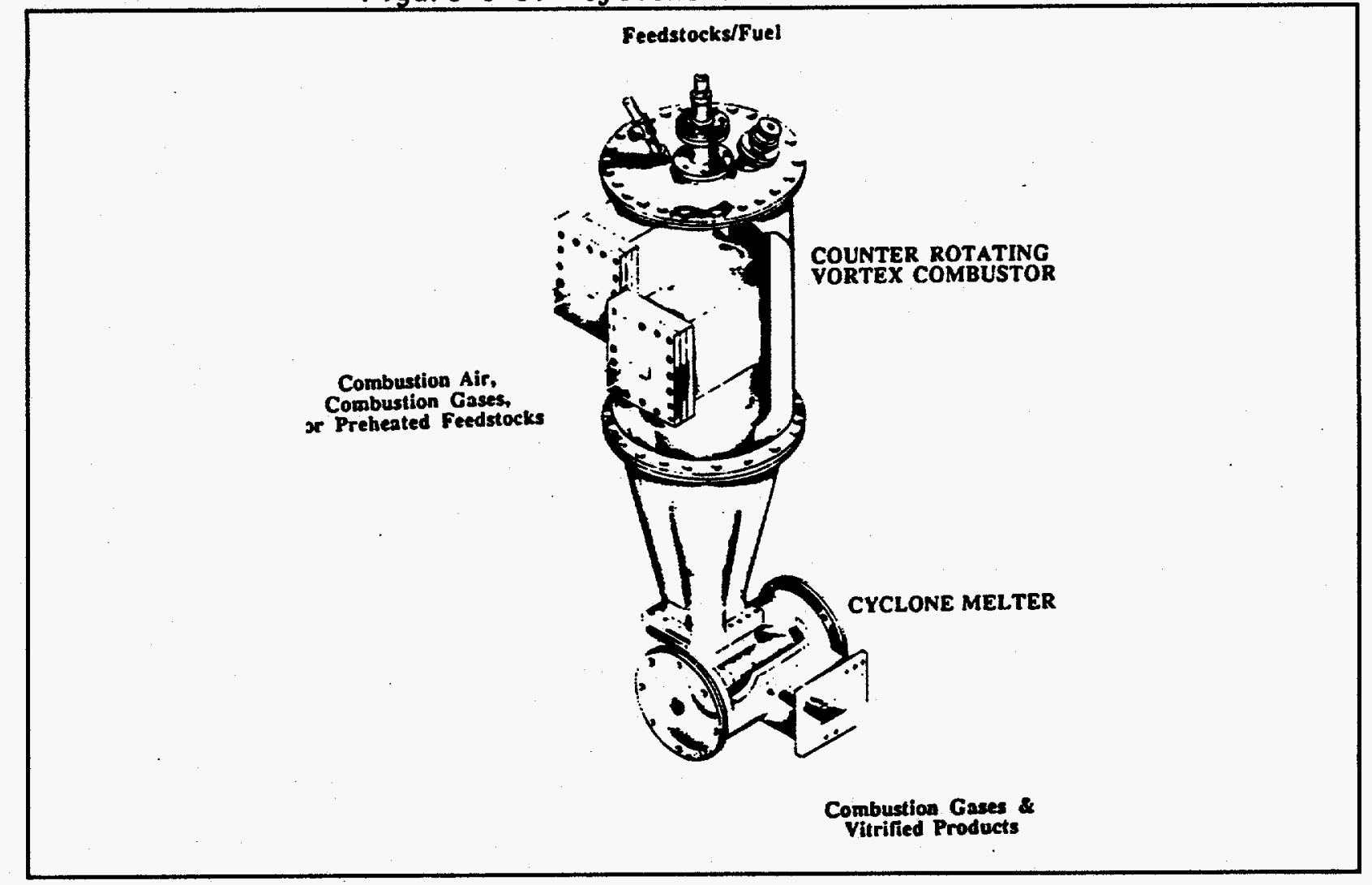




\section{C3.0 INDUCTION HELTERS}

Induction melters provide energy to the glass batch by magnetic induction. The glass tank is surrounded by an induction coil. Depending on the frequency of the induction coil and the materials of construction for the tank, the heating is either provided to the metal crucible or directly to the glass. These meiters are usually dry fed and are coupled to a calciner or evaporator when used with slurries.

\section{C3.1 LOW-FREQUENCY INDUCTION MELTERS}

Low-frequency induction melters consist of a metal (usually Inconel) crucible surrounded by an induction coil. The induction coil heats the metal crucible by magnetic induction which, in turn, heats the glass by thermal conduction. This type of melter has been used for vitrification of radioactive reprocessing wastes in both France and England. The scale of this type of melter is limited because the heating is provided only to the outer surface of the melter. The maximum capacity of such systems is approximately $30 \mathrm{~kg} / \mathrm{h}$. The maximum operating temperature is usually around $1100^{\circ} \mathrm{C}$.

\section{C3.2 HIGH-FREQUENCY INDUCTION MELTERS}

Unlike conventional, low-frequency induction melters, high-frequency induction metters couple the induction field directly to the glass. This is accomplished by breaking up the metal crucible into isolated vertical sectors, cooling the sectors, and increasing the frequency of the induction signal (see Figure (-6). Because the crucible is cooled on the exterior surface, a layer of cooled glass protects the crucible from corrosion.

This protective layer allows the bulk of the melter to be run at very high temperatures so that higher glass waste loadings, production rates, and meiting of refractory compounds can be achieved. These melters are also referred to as cold-wall and cold-crucible melters (CCM). They were originally developed for metal melting and have been adapted to waste glass melting in France and Russia. They are also used extensively to produce garnets, etc. The important parameters to be controlled are the frequency of the induction signal, the electrical resistivity of the material to be heated (glass in this case), and the penetration depth of the induced currents. The smaller the CCM, the higher the induction frequency that is required. There are size limits imposed on the CCM by these parameters. Small CCMs $(<15 \mathrm{~cm})$ are difficult to heat because the required induction frequency is very high and an appropriate signal generator is required. Large CCMs are difficult to heat because the induction frequency is so. low that it will not couple to the glass. The electrical resistivity of glass is strongly temperature-dependent. For this reason, the glass in a CCM must be preheated at the beginning of a run before induction heating can begin (similar to joule-heated melters). This has been done using microwave heating or starter paths.

Several thousand hours have been logged on the glass-melting CCMs. The CCMs can be operated at very high temperatures because they are skull-type melters. Operating temperatures as high as $2800^{\circ} \mathrm{C}$ have been reported. The maximum glass production capacity has been $25 \mathrm{~kg} / \mathrm{h}\left(260 \mathrm{~kg} / \mathrm{h} / \mathrm{m}^{2}\right)$ for a $35-\mathrm{cm}$ 
Figure C-6. Cyclone Combustion Me1ter.

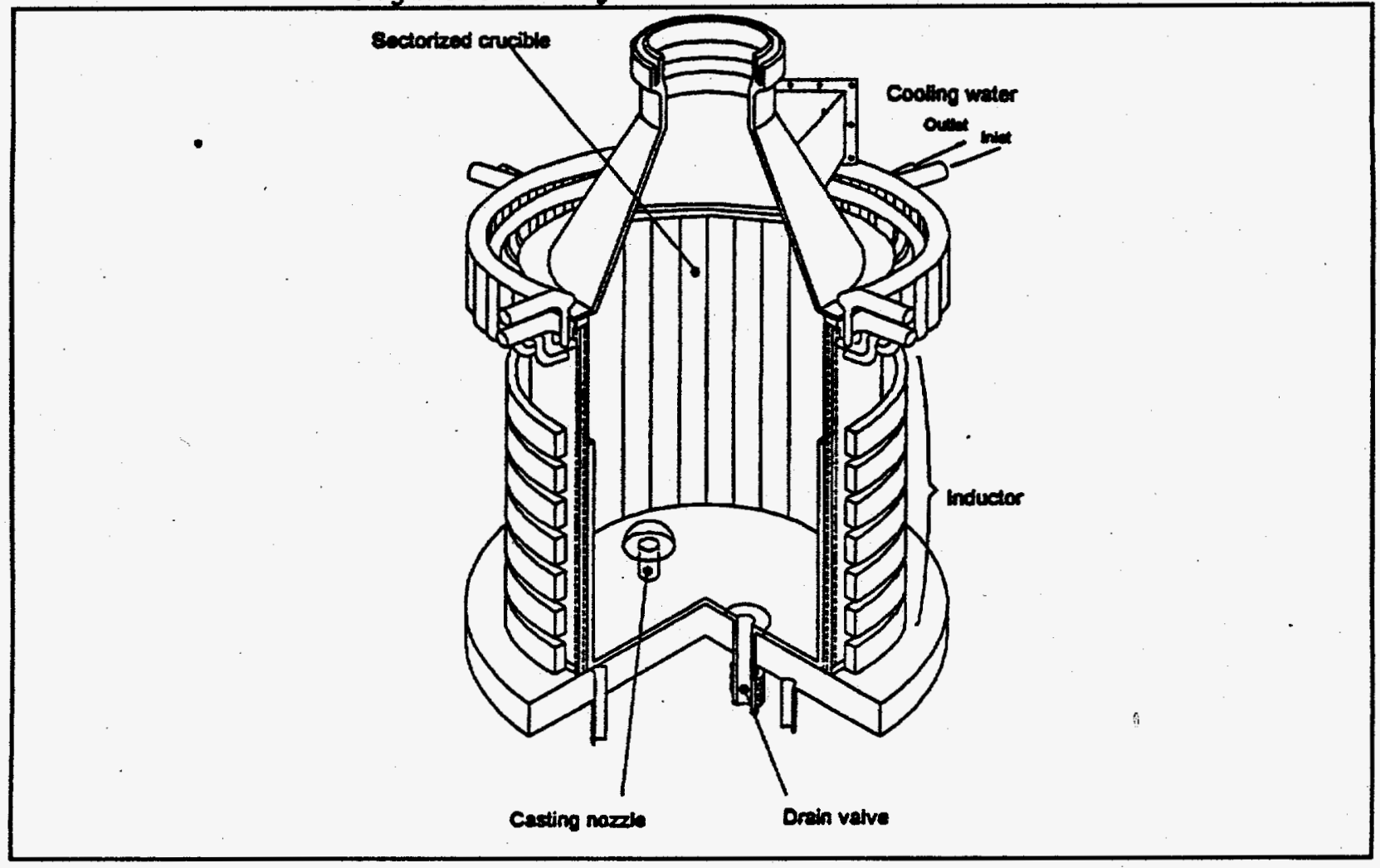

diameter $\mathrm{CCM}$ and $50 \mathrm{~kg} / \mathrm{h}\left(210 \mathrm{~kg} / \mathrm{h} / \mathrm{m}^{2}\right)$ for a $55-\mathrm{cm}$ diameter $\mathrm{CCM}$. Because of the relationship between melter diameter and induction frequency, the scaleup is limited for this type of melter. The maximum melter size demonstrated to date is $1.2 \mathrm{~m}$ in diameter.

\section{C4.0 PLASMA/ARC FURNACES}

This category can be broken up into three subgroups: plasma torches, transferred plasma arc melters, and arc furnaces.

\section{C4.1 PLASMA TORCHES (ENTRAINED AND INDIRECT)}

Plasma torches (non-transferred arc) operate by injecting a pressurized gas into a direct current electric arc. The resulting vortex of hot plasma gases emerges at a very high speed to form the stabilized plasma. The heart of the plasma torch is two water-cooled electrodes arranged closely to each other (sometimes coaxially) so that an arc is created when current is applied to the system. The anode usually serves as the torch nozzle. A pressurized gas (argon, air, nitrogen, oxygen, etc.) is introduced through the arc gap between the electrodes and ionized to form the hot plasma. Melters designed around plasma torches rely on impinging the torch on a crucible and passing the material to be melted through the crucible, or simply passing the material through the plasma. The crucibles are usually constructed from graphite, 
refractory material, or water-cooled metal. The melters can operate in either a batch or continuous mode at very high temperatures (up to $3000^{\circ} \mathrm{C}$ ). The torch tips usually have a very short ilfe and need to be replaced after approximately 100 hours of use. The crucibles are usually shallow because the heat is supplied from the top surface and radiant heat transfer is poor through most wastes.

\section{C4.2 TRANSFERRED PLASMA ARC MELTERS}

Transferred plasma arc melters operate under principles similar to those for plasma torches except that either the melted material or the crucible serves as one of the electrodes. This allows for more equal distribution of heat as well as joule heating of the material. Typically, the electrode is still water-cooled metal, although this configuration does allow the electrode to be constructed of a material that does not have to be water cooled (e.g., graphite). By the use of nonmetallic electrode materials, the operating current density can be increased substantially thereby increasing the energy transfer while still maintaining a short arc length. Operating with shorter arcs minimizes the energy losses, concentrating the heat into the material to be melted. In addition, graphite electrodes allow operation in a submerged mode thus minimizing volatilization losses that are usually substantial for such systems.

\section{C4.3 ARC FURNACES}

Arc furnaces operate very similarly to transferred plasma arc melters except that pressurized gas is not passed through the electrode. The plasma gas is either the surrounding air or the cover gas if the vessel is blanketed. These furnaces can use either alternating current or direct current to create the arc. Three-phase alternating current systems are commonly used for production of alloys, silicon, etc. Because most of these systems use carbon or graphite electrodes, the furnaces are usually run under a reducing atmosphere. The resulting product is usually reduced and somewhat crystalline.

\section{C5.0 MICROWAVE MELTERS}

Microwave melters heat the glass batch by direct coupling of a highfrequency wave to the glass. The principles of this technique are similar to those for high-frequency induction melters discussed earlier. The advantage of using higher frequency heating, such as microwaves, is that they can couple to cold glass and do not require an auxiliary startup system. The disadvantage is that the penetration depth is even more limited than in induction heating. Microwave heating systems have been used for in-container solidification of radioactive wastes including incinerator ashes, sludges, and soils. The waste materials are vitrified inside a metal disposal container in either a batch or continuous feed mode. Melt temperatures range from 980 to $1420{ }^{\circ} \mathrm{C}$. Operational problems resulting from uneven melting of the wastes, especially near the bottom and sides of the container, have been experienced, as we 11 as melt-through of the container at hot spots (DOE 1991). 
WHC-EP-0847

\section{C6.0 ROTARY KILNS}

Rotary kilns for waste treatment operate similarly to cement kilns. A ceramic-lined, rotating cylinder is inclined at a slight angle. Solid or liquid waste is fed into the upper end of the cylinder and heat is supplied at the lower end by fossil fuel burners. The waste slowly flows down the kiln, eventualiy exiting the lower end. Depending on the operating temperature of the kiln and the waste type, the waste exits the lower end as either a solid or a molten material. Operating temperatures of rotary kilns greatly exceed $1200^{\circ} \mathrm{C}$. Both the $\mathrm{kiln}$ and the required offgas system are very large on these systems. To date, waste treatment with these systems has been limited to liquid wastes, soils, and ashes. Durable glass has been produced from municipal solid waste incinerator ash (Harlow et al. 1990). Simulated HLW has not been melted in such systems.

\section{C7.0 HOT ISOSTATIC PRESSING}

Hot isostatic pressing has been demonstrated in Australia (i.e., at Synroc) and Russia for mineralization of radioactive wastes. The process starts by calcining and denitrating the waste in either a rotary calciner, spray calciner, or flash calciner. The resulting calcine is mixed with the mineral precursor (garnet, titanium, zirconium, aluminum, etc.) and pressed at 1000 to $1200{ }^{\circ} \mathrm{C}$ and 14 to $20 \mathrm{MPa}$ for about 2 hours. The calcination and pressing is carried out in a reducing atmosphere to suppress formation of soluble molybdates (e.g., cesium molybdate) and pertechnetates (Radioactive Waste Forms for the Future, pp. 233-333, "Synroc" [Ringwood et a1. 1988]). The resulting product resembles a natural mineral. Waste loadings of 10 to 20 wt\% are normally obtained. The Synroc formulation incorporates the entire $\mathrm{HLW}$ stream into a multiphase titanate matrix (zirconolite $\left[\mathrm{CaZrTi}_{2} \mathrm{O}_{7}\right]$; barium hollandite $\left[\mathrm{BaAl}_{2} \mathrm{Ti}_{6} \mathrm{O}_{16}\right]$; and perovskite $\left[\mathrm{CaTiO}_{3}\right]$ ) (Levins et a1. 1986). Russian research is focusing on partitioning the HLW stream, vitrifying the cesium and strontium fractions, and hot isostatic pressing the other

fractions. Several minerals are being investigated for HLW mineralization: stabilized cubic zirconium dioxide, garnets, zirconium silicates, rare earth phosphates, and titanates.

\section{C8.0 IN-CAN MELTER}

The in-can melter was developed in the early 1970's for vitrification of high-level radioactive waste. The units consisted of a dryer (wiped-film evaporators were demonstrated) or calciner (rotary or spray) coupled to a heated canister. The dryer or calciner would convert the incoming slurry to a solid powder. The powder would fall into an alloy canister where it would be converted into a glass. Liquid feeding was also demonstrated. The canisters were usually constructed out of 304L stainless steel although Inconel 601 was also tested. This was a semi-batch process where the canister would be fed until it was full. After a soak period, the canister was replaced with another canister. Heating to the canister was usually provided by external 
resistance heaters that surrounded the canister, although induction heaters were also demonstrated. The in-can melters usually operated at 1000 to $1100{ }^{\circ} \mathrm{C}$. Processing rates and melter scaleup were 1 imited because the heating was provided from the outside of the canister. The largest canister tested at PNL was $71 \mathrm{~cm}$ (28 in.) in diameter. Heat transfer fins were inserted into the center of large canisters to increase radial heat transfer. The highest melting rate recorded was $117 \mathrm{~kg} / \mathrm{h}$. Because of the low operating temperatures, the glass durability was usually a factor of five to ten lower than glasses produced at higher temperatures $\left(1150^{\circ} \mathrm{C}\right)$. Mixing was al so a problem with the in-can melters. Clinkers of undissolved feed and frit were found in several instances, and glass homogeneity was also a problem.

\section{C9.0 REFERENCES}

DOE, 1991, An Assessment of Thermal Destruction Technologies for Application to Department of Energy Mixed Wastes, Volume 1, Technology Assessment, D0E/HWP-106, Hazardous Waste Remedial Actions Program, U.S. Department of Energy, Washington, D.C.

Harlow, G. L., C. A. Whitehurst, and H. Robards, 1990, "Ash Vitrification - A Technology Ready for Transfer," National Waste Processing Conference, June 3-6, Longbeach, Cal ifornia.

Larson, D. E., 1989, Hanford Waste Vitrification Plant Technical Manual, HWVP-89-iVJ0010100A, Pacific Northwest Laboratory, Richland, Washington.

Levins, D. M., K. D. Reeve, W. J. Buykx, R. K. Bryan, B. W. Seatonberry, J. L. Woolfrey, and K. P. Hart, 1986, "Fabrication and Performance of Synroc," Proceedings of the American Nuclear Society International Topical Meeting, Waste Management and Decontamination and Decommissioning, September 14-18, Niagara Falls, New York.

Pincus, A. G., 1980, Melting Furnace Design in the Glass Industry, Books for Industry, New York, New York.

Ringwood, A. E., S. E. Kesson, K. D. Reeve, D. M. Levins, and E. J. Ramm, 1988, Radioactive Waste Forms for the Future, North-Holl and, a Division of Elsevier Science Publishers B.V., Amsterdam, The Netherlands.

Tooley, F., 1974, The Handbook of Glass Manufacture, Books for Industry, New York, New York.

Tooley, F., 1991, Engineered Materials Handbook, ASM International, Meadows Park, Ohio.

Trier, W., 1987, Glass Furnaces, Society of Glass Technology, Sheffield, England.

Woolley, F. E., 1991, Engineered Materials Handbook, ASM International, Meadows Park, Ohio. 
WHC-EP-0847

\section{C10.0 GLOSSARY}

\section{ABBREVIATIONS AND ACRONYMS}

AZS alumina zirconia silica

CCM cold-crucible melter

HLW

high-level waste

MSWG Melter Selection Working Group 
This page intentionally left blank. 
WHC-EP-0847

APPENDIX D

TECHNICAL ADVISORY BOARD RECOMMENDATION LETTER

D-1 

WHC-EP-0847

APPENDIX D

\section{TECHNICAL ADVISORY BOARD RECONMENDATION LETTER}

The following is a transcript of the Technical Advisory Committee's (TAC) recommendation.

Two workshops were conducted to perform this work. During a threeday workshop in June, a wide range of melting technologies was considered. Broad criteria were used to select technologies for detailed review. This process reduced fifteen original candidate technologies to six all-electric melter alternatives. More

information was gathered on these six prior to the August workshop. The six melting technologies selected for detailed study are widely used in industrial applications or are currently being considered for vitrification of $H L W$. The group did not identify sufficient advantages in other types of melters, such as combustion or plasma, to include them in the second, more detailed evaluation. 
In the August workshop seven criteria with specific attributes were used to systematically evaluate the issues associated with the six proposed technologies. The result was the elimination of two of the remaining six, and the regrouping of the remaining four into one primary technology, electric melting with electrodes, with three variants, and a backup technology, high-frequency induction melting.

At the end of this workshop the external Technical Advisory Committee was very confident that the Hanford HLW can be successfully vitrified with the selected technologies, and that the selection/evaluation process uncovered all significant technical issues with each of the technologies considered. The diversity of backgrounds of the participants, and the thorough preparation of reference information, eliminated any tendency to discard a technology because of unfamiliarity. There were no significant differences between the final conclusions drawn by the external and the WHC participants.

\section{CONCLUSIONS FROM THE AUGUST WORKSHOP}

1. All-electric cold-top melters with nicke1-based electrodes, developed initially at Westinghouse Hanford and further developed for worldwide use, provide a solid base technology for high-level waste vitrification. Existing melter concepts should be capable of processing most of the HLW streams at reasonable waste loadings. Larger capacity melters need to be developed to meet production rate requirements.

2. High melter temperatures offer the potential for large reductions in total program costs through increased melting efficiencies, higher waste loadings (fewer canisters to store), less need for waste blending, and lower operating and disposal costs for fewer or smaller melters. The constraints imposed on glass composition and waste loading by low-temperature nickelbased electrodes should be removed by an appropriate development program.

3. Of the two methods for achieving high temperature, the first choice is for melters with electrodes. This makes maximum use of the existing $H \mathrm{LW}$ and industrial melting experience, and is considered the approach with the highest probability of success. Major development efforts should be focused on electrode materials resistant to attack by Hanford waste components.

4. High-frequency induction melting offers the significant advantage of relief from problems of electrode attack but should be considered a strong backup technology because of the relative immaturity of both melters and power supplies. Initial testing should focus on potential compatibility issues specific to the high-pH, high-sodium Hanford wastes. 
5. Several refinements are available to improve the performance of both types of electric melters, and these should be developed further. These are completely compatible with the basic electric melting technologies and could be incorporated without fundamental changes. However, reliability of any melter is strongly reduced by complexity, and this consideration reduces the attractiveness of these approaches.

- Agitation, by bubbling or by mechanical stirring (with a rotating electrode or other stirrer), can greatiy increase melting rate, thus reducing the number of melters needed or their size.

- Feed drying or calcining can significantly reduce the power that must be supplied by electrodes or highfrequency power supplies, thus reducing the size or number of melters.

- Sloped bottoms may be needed to minimize deposits of noble metals and other insoluble components.

6. Unfortunately, scaleup of glass melters is at present an experimental process, and frequent $7 y$ produces surprises. Full-scale testing should be undertaken as soon as practical. However, development time and costs can be substantially reduced by thorough small-scale materials testing and by full use of both small-and full-scale tests of key design features (e.g., drain valves, electrode arrangements) before testing total melter systems. Development time and cost can be further reduced by extensive use of mathematical models of the types used by all major developers of industrial glass melters.

7. Very large reductions in total program costs could result from an ample development program. Although the present nickelbased electrode melter technology is quite mature, the potential savings from the other technologies discussed here greatly exceed their development costs. The program should include substantial efforts on (a) high temperature electrode materials and designs, (b) glass compositions to take full advantage of higher melting temperatures, (c) high frequency induction melter design and power supplies, (d) melt agitation and feed drying methods, and (e) fult-scale testing of key design features and total melter systems.

8. Flexibility in the remote facility design could substantially reduce total program costs by allowing melter improvements and substitution of alternate melter technologies after initial startup. Hot cells and support facilities should be designed on the assumption that the melting development program suggested above will be fully successful and that improved melters will become available during the useful life of the facilities. For example, extra height would allow top-entering electrodes or sloped bottoms to be retrofitted, while space for Jarger power supplies would allow additional melter cooling or higher temperature operation for troublesome feed streams. 
A wide range of other melting technologies was considered during this review process. These include processes developed for $H L W$ vitrification and commercial glass production. They are listed below along with reasons for eliminating them from the selection process. In general, they were eliminated because they had no significant advantages compared to the selected processes or because any potential advantages were offset by high technical risks and long development times and costs.

Two technologies were sufficiently promising that they were eliminated only after a second, more detailed evaluation in the August workshop.

1. Low-frequency, Induction Melter. This technology (AVH) was developed in France and has been implemented at the Marcoule, LatHague and Sellafield waste sites. Although it is a fully developed process for small-scale (low volume) HLW vitrification, the potential for scaleup to larger units is very limited. To meet the Hanford waste glass production rate criteria, up to 28 parallel lines of AVH systems could be required. This large number of operating melters leads to excessive facility construction and operating costs. In addition, radiation exposure to the staff maintaining the manipulators needed to operate this technology could be high.

2. High-temperature, Cold-wall, Joule-heated Melters. Electrodes positioned near the center of this type of melter generate a small volume of glass at very high temperature. The metal melter walls are protected from corrosion by a layer of cold glass maintained by water cooling of the jacket. Concerns regarding high electrode corrosion (accelerated by the excessive glass temperature) and the lack of discernable advantages over other melters with electrodes eliminated this option from further consideration.

The remaining technologies were eliminated in the first round because of fundamental limitations making it highly unlikely that a satisfactory process could be developed within any reasonable resource and schedule constraints.

1. Combustion Melters and Rotary Kilns. Most of the commercial glass melted today is produced in furnaces heated by combustion of fossil fuels, where the batch pile and open melt surfaces are heated by radiation from the flames. The exceptions are glasses containing components that volatilize easily from hot surfaces. For these applications, all-electric melters covered by cold batch layers (similar to the liquid-feed ceramic melter concept) are employed. Volatile components are lost especially rapidly if the feed stream is directly exposed to the hightemperature flames; this is the basic problem with cyclone combustion melters, and the reason they are not used commercially. The major issue that removed these alternatives from any further consideration was the fundamental problem of 
volatilization of cesium, technetium, and other heavy metals and alkalies in Hanford HLW. In addition, there were concerns about the institutional safety issues associated with explosive gases in a HLW processing cell. A major testing and development program would be required to identify and resolve the technical issues related to the known fundamental problems, the immaturity of the technology, and the lack of operational data. This technology was judged to have a low probability of success within resource and schedule constraints.

2. Plasma and Arc Furnaces. These furnaces offer the potential to melt very refractory materials and to accept feed in large packages, but these are not characteristics of the Hanford Site HLW. The expected life of plasma torch electrodes is generally measured in hours or days. Excessive maintenance of plasma torch electrodes, volatilization of radionuclides at the high torch or arc operating temperatures, and concerns about the quality of HLW glasses (due to the short residence times and reducing conditions characteristic of these furnaces) were the issues which eliminated these options.

3. Microwave Melters and Hot Isostatic Presses. Each of these techniques has been proposed for HLW solidification. The combination of issues related to scale-up, close control of feed materials, questionable product quality, throughput capacity of each unit, development time, and technical risks was the primary reason for removing these options from further consideration.

4. In-can Melting. This option is among the least complex of the alternatives, has been demonstrated with $H L W$, and can be operated with either dried or slurry feed. However, production rates are limited and the uniformity of the canisterized product is poor and not verifiable during production. The range of glass melting temperatures is al so limited by the stainless steel canister. This was not considered a viable option for future Hanford waste vitrification. 
WHC-EP-0847

This page intentionally left blank. 
WHC-EP-0847

APPENDIX E

TANK WASTE REMEDIATION SYSTEN DECISION

BOARD RECOMMENDATIONS

E-1 
WHC-EP-0847

This page intentionally left blank. 


\section{CORRESPONDENCE DISTRIBUTION COVERSHEET}

Author

R. B. Cairnus, 376-5017
Addressee

Mr. L. Erickson, RL
Correspondence No.

9456834

Subject: HIGH LEVEL WASTE MELTER ALTERNATIVES ASSESSMENT DECISION

INTERNAL DISTRIBUTION

Approval

Date

Mame

Correspondence Control

President's Office

R. B. Calmus

x R.F. Ermoled rolelis

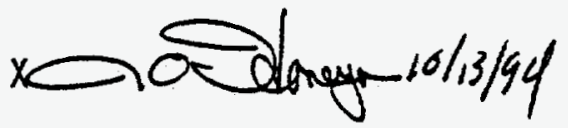

$\times 1$ WK for RCR $10 \cdot 11 \cdot 94$

L. F. Ermold

K. A. Gasper

J. 0 . Honeyman

R. J. Murkowski

R. W. Powel1

R. C. Roal

Location

w/att

A3-01

$x$

B3-01

H5-27

$57-84$

G3-21

57-81

R4-01

H4-14

H5-27

R. A. Smith

G6-02

D. J. Washenfelder

H5-27

E. T. Weber

H5-27

G. F. Williamson

R4-01

R. D. Wojtasek

S7-84

RBC File/LB

H5-27

W. T. Alumkal

57-85

$x$

$x$

$x$

$x$

$x$

$x$

$x$

$x$

$x$

$x$

$x$

$x$

$x$

$x$

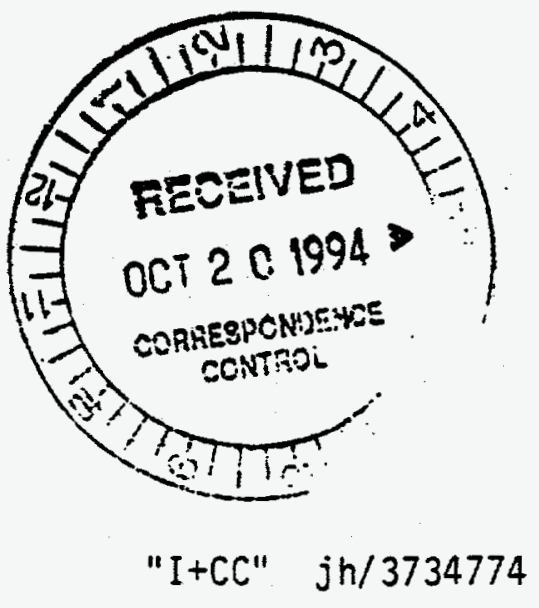


P.O. Box 1970 Richland, WA 99352

October 18, 1994

Mr. L. Erickson, Director

Tank Waste Retrieval, Treatment,

and Immobilization Division

U.S. Department of Energy

Richland Operations Office

Richland, Washington 99352

Dear Mr. Erickson:

\section{HIGH LEVEL WASTE MELTER ALTERNATIVES ASSESSMENT DECISION}

Reference: Letter, W. T. Alumkal, WHC, to T. R. Sheridan, RL, "Configuration Selection for the Tank Waste Remediation System," 9454691, dated July 18, 1994.

A major objective of the Tank Waste Remediation System (TWRS)

Fiscal Year 1994 High-Level Waste (HLW) Program scope was assessment of potential HLW melter systems. This letter transmits results of that assessment activity and a description of the process used to establish the Westinghouse Hanford Company (WHC) TWRS meiter system development program recommendation. This documentation represents completion of U.S.

Department of Energy, Richland Operations Office milestone TDE-94-424, "Report on Alternative Melter Candidate Assessment Decision."

An assessment process which used a Technical Advisory Committee of external (nonHanford) experts in commercial and HLW glass processing was defined. A working group was built around this Technical Advisory Committee using experienced WHC staff and other U.S. Department of Energy (DOE) complex and international HLW melter experts (see attachment for listing of team members). The goal of the assessment process was to recommend technologies and development program focus areas which have the highest potential to meet HLW Program objectives.

Starting with a list of 15 melter system technologies, the evaluation team narrowed the options for detailed consideration by performing an initial screening evaluation. A recommendation on preferred melter technologies and technology development direction was prepared by the Technical Advisory Committee. The enclosure provides a summary description of the melter assessment process, the full text of the Technical Advisory Committee recommendation, and summary of the application of results.

Key elements of the recommendation are:

- All-electric, cold-top melters with nickel-based electrodes represent a solid base technology for vitrification of Hanford high-level waste. 
Mr. L. Erickson

9456834

Page 2

October 18, 1994

Primary emphasis should be placed on developing high temperature capabilities for this technology and variations in features to increase waste processing capacity and improve performance.

- High-frequency induction melting offers significant advantages, including relief from problems of electrode attack, but should be considered a backup technology because of the relative immaturity of these melter systems.

- Other points of the recommendation focus on the need for development and testing of small- and large-scale test systems, cost/benefit considerations of an ample development program, and benefits of developing flexibility in the remote facility design to allow future installation of alternative, improved technologies.

This recommendation has been reviewed and accepted by senior TWRS management using a decision process analogous to that employed in the Facility Configuration Selection decision (Reference). Based on this review, WHC recommends that the results of the independent external review panel's assessment be accepted and implemented for the baseline HLW melter development approach. WHC will continue to evaluate feasibility of other technologies that could provide substantial benefit over the baseline technologies for our application.

We request your concurrence with our decision to implement the recommendation from the HLW Melter Alternatives Assessment as a basis for revising the HLW program baseline for melter system development and demonstration.

If you have any questions or require further information, please contact Dr. R. W. Powell at (509) 376-9618.

Very truly yours,
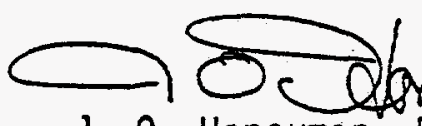

J. 0. Honeyman, Direstor

Disposal Programs

Tank Waste Remediation System

lap $\backslash$ tb

Attachment

RL - K. W. Bracken

L. A. Huffman

R. L. Long, Jr.

J. C. Peschong

R. 0 . Puthoff (w/0 enclosure)

G. H. Sanders

PNL - W. J. Apley 


\section{HIGH-LEVEL WASTE ALTERNATIVE MELTER CANDIDATE ASSESSMENT REPORT}

\subsection{INTRODUCTION AND BACKGROUND}

The mission of the Hanford Site High-level Waste Disposal Program is to convert the Site's high radiation-level defense waste, currently stored in underground tanks, into an encapsulated glass product qualified for final disposal in a federal geological repository.

Changes in the expected quantity of high-level waste (HLW) have resulted in substantial increases in needed vitrification plant capacity compared to the previous Hanford Waste Vitrification Plant (HWVP) capacity and defense waste processing facility (DWPF) capacity. This will require the Tank Waste Remediation System (TWRS) Program to immobilize double-shell tank and singleshell tank waste in a vitrification plant with a waste-processing capacity (a function of glass production capacity and waste loading) four to eight times higher than that of the HWVP design.

An assessment of potential vitrification technologies for processing the Hanford Si.te's HLW volume was performed in Fiscal Year (FY) 1994. The following sections include the Technical Advisory Committee's recommendation, a summary of the assessment process used to arrive at the decision, a list of assessment activity participants, the technologies considered, the subset of technologies receiving detailed evaluation, and discussion of the application of the recommendation.

\subsection{TECHNICAL ADVISORY COMMITTEE RECOMMENDATION}

The assessment group's primary responsibility was to provide a recommendation on which a development program could be based with the highest probability of success in providing an operable, cost-effective vitrification system, with acceptable performance and within program constraints.

The following is a transcript of the Technical Advisory Committee's recommendation.

Two workshops were conducted to perform this work. During a threeday workshop in June, a wide range of melting technologies was considered. Broad criteria were used to select technologies for detailed review. This process reduced fifteen original candidate technologies to six all-electric melter alternatives. More information was gathered on these six prior to the August workshop. The six melting technologies selected for detailed study are widely used in industrial applications or are currently being considered for vitrification of $H L W$. The group did not identify sufficient advantages in other types of melters, such as combustion or plasma, to include them in the second, more detailed evaluation. 
In the August workshop seven criteria with specific attributes were used to systematically evaluate the issues associated with the six proposed technologies. The result was the elimination of two of the remaining six, and the regrouping of the remaining four into one primary technology, electric melting with electrodes, with three variants, and a backup technology, high-frequency induction melting.

At the end of this workshop the external Technical Advisory Committee was very confident that the Hanford HLW can be successfully vitrified with the selected technologies, and that the selection/evaluation process uncovered all significant technical issues with each of the technologies considered. The diversity of backgrounds of the participants, and the thorough preparation of reference information, eliminated any tendency to discard a technology because of unfamiliarity. There were no significant differences between the final conclusions drawn by the external and the WHC participants.

\section{CONCLUSIONS FROM THE AUGUST WORKSHOP}

1. "All-electric cold-top melters with nickel-based electrodes, developed initially at Westinghouse Hanford and further developed for worldwide use, provide a solid base technology for high-level waste vitrification. Existing melter concepts should be capable of processing most of the HLW streams at reasonable waste loadings. Larger capacity melters need to be developed to meet production rate requirements."

2. High melter temperatures offer the potential for large reductions in total program costs through increased melting efficiencies, higher waste loadings (fewer canisters to store), less need for waste blending, and lower operating and disposal costs for fewer or smaller melters. The constraints imposed on glass composition and waste loading by low-temperature nickelbased electrodes should be removed by an appropriate development program.

3. Of the two methods for achieving high temperature, the first choice is for melters with electrodes. This makes maximum use of the existing HLW and industrial melting experience, and is considered the approach with the highest probability of success. Major development efforts should be focused on electrode materials resistant to attack by Hanford waste components.

4. High-frequency induction melting offers the significant advantage of relief from problems of electrode attack but should be considered a strong backup technology because of the relative immaturity of both melters and power supplies.

Initial testing should focus on poteritial compatibility issues specific to the high-pH, high-sodium Hanford wastes. 
5. Several refinements are available to improve the performance of both types of electric melters, and these should be developed further. These are completely compatible with the basic electric melting technologies and could be incorporated without fundamental changes. However, reliability of any melter is strongly reduced by complexity, and this consideration reduces the attractiveness of these approaches.

- Agitation, by bubbling or by mechanical stirring (with a rotating electrode or other stirrer), can greatly increase melting rate, thus reducing the number of melters needed or their size.

- Feed drying or calcining can significantly reduce the power that must be supplied by electrodes or highfrequency power supplies, thus reducing the size or number of melters.

- Sloped bottoms may be needed to minimize deposits of noble metals and other insoluble components.

6. Unfortunately, scaleup of glass melters is at present an experimental process, and frequently produces surprises. Full-scale testing should be undertaken as soon as practical. However, development time and costs can be substantially reduced by thorough small-scale materials testing and by full use of both small- and full-scale tests of key design features (e.g., drain valves, electrode arrangements) before testing total melter systems. Development time and cost can be further reduced by extensive use of mathematical models of the types used by all major developers of industrial glass melters.

7. Very large reductions in total program costs could result from an ample development program. Although the present nickelbased electrode melter technology is quite mature, the potential savings from the other technologies discussed here greatly exceed their development costs. The program should include substantial efforts on (a) high temperature electrode materials and designs, (b) glass compositions to take full advantage of higher melting temperatures, (c) high frequency induction melter design and power supplies, (d) melt agitation and feed drying methods, and (e) full-scale testing of key design features and total melter systems.

8. Flexibility in the remote facility design could substantially reduce total program costs by allowing melter improvements and substitution of alternate melter technologies after initial startup. Hot cells and support facilities should be designed on the assumption that the melting development program suggested above will be fully successful and that improved melters will become available during the useful life of the 
facilities. For example, extra height would allow top-entering electrodes or sloped bottoms to be retrofitted, while space for larger power supplies would allow additional melter cooling or higher temperature operation for troublesome feed streams.

\section{TECHNOLOGIES NOT RECOMMENDED FOR FURTHER DEVELOPMENT}

A wide range of other melting technologies was considered during this review process. These include processes developed for $H L W$ vitrification and commercial glass production. They are listed below along with reasons for eliminating them from the selection process. In general, they were eliminated because they had no significant advantages compared to the selected processes or because any potential-advantages were offset by high technical risks and long development times and costs.

Two technologies were sufficiently promising that they were eliminated only after a second, more detailed evaluation in the August workshop.

1. Low-frequency, Induction Melter. This technology (AVH) was developed in France and has been implemented at the Marcoule, LaHague and Sellafield waste sites. Although it is a fully developed process for small-scale (low volume) $H L W$ vitrification, the potential for scaleup to larger units is very limited. To meet the Hanford waste glass production rate criteria, up to 28 parallel lines of AVH systems could be required. This large number of operating melters leads to excessive facility construction and operating costs. In addition, radiation exposure to the staff maintaining the manipulators needed to operate this technology could be high.

2. High-temperature, Cold-wall, Joule-heated Melters. Electrodes positioned near the center of this type of melter generate a small volume of glass at very high temperature. The metal melter walls are protected from corrosion by a layer of cold glass maintained by water cooling of the jacket. Concerns regarding high electrode corrosion (accelerated by the excessive glass temperature) and the lack of discernable advantages over other melters with electrodes eliminated this option from further consideration.

The remaining technologies were eliminated in the first round because of fundamental limitations making it highly unlikely that a satisfactory process could be developed within any reasonable resource and schedule constraints.

1. Combustion Melters and Rotary Kilns. Most of the commercial glass melted today is produced in furnaces heated by combustion of fossil fuels, where the batch pile and open melt surfaces are heated by radiation from the $f 7$ ames. The exceptions are glasses containing components that volatilize easily from hot surfaces. For these applications, all-electric melters covered by cold batch layers (similar to the liquid-feed ceramic melter concept) are employed. Volatile components are lost especially rapidly if the feed stream is directly exposed to the high- 
temperature flames; this is the basic problem with cyclone combustion melters, and the reason they are not used commercially. The major issue that removed these alternatives from any further consideration was the fundamental problem of volatization of cesium, technetium, and other heavy metals and alkalies in Hanford $H \mathrm{HW}$. In addition, there were concerns about the institutional safety issues associated with explosive gases in a HLW processing cell. A major testing and development program would be required to identify and resolve the technical issues related to the known fundamental problems, the immaturity of the technology, and the lack of operational data. This technology was judged to have a low probability of success within resource and schedule constraints.

2. Plasma and Arc Furnaces. These furnaces offer the potential to melt very refractory materials and to accept feed in large packages, but these are not characteristics of the Hanford Site $H L W$. The expected life of plasma torch electrodes is generaily measured in hours or days. Excessive maintenance of plasma torch electrodes, volatilization of radionuclides at the high torch or arc operating temperatures, and concerns about the quality of $H L W$ glasses (due to the short residence times and reducing conditions characteristic of these furnaces) were the issues which eliminated these options.

3. Microwave Melters and Hot Isostatic Presses. Each of these techniques has been proposed for HLW solidification. The combination of issues related to scale-up, close control of feed materials, questionable product quality, throughput capacity of each unit, development time, and technical risks was the primary reason for removing these options from further consideration.

4. In-can Melting. This option is among the least complex of the - alternatives, has been demonstrated with $\mathrm{HLW}$, and can be operated with either dried or slurry feed. However, production rates are limited and the uniformity of the canisterized product is poor and not verifiable during production. The range of glass melting temperatures is also limited by the stainless steel canister. This was not considered a viable option for future Hanford waste vitrification.

\subsection{ASSESSMENT PROCESS DESCRIPTION}

The HLW vitrification system assessment was conducted in two phases. Each phase culminated in a workshop to bring Melter Selection Working Group (MSWG) participants, technical resource staff, and various stakeholder groups together to perform the assessment and to document assessment results. 
A modified Kepner-Tregoe decision-making process was used to assess the technologies and to provide ratings to form the basis from which the most viable technologies could be selected. The process entailed these steps.

1. Review and reach shared understanding of the results to be achieved.

2. Establish the criteria and attributes important to the evaluation and identify any "must" or "go" or "no go" attributes.

3. Compare the technologies against the criteria.

- Phase I was an initial down-selection, evaluating the probability of success for the technologies to reduce the list to a manageable number.

- Phase II was a detailed assessment and scoring of technologies based on a study of additional data covering the characteristics of the technologies compiled after Phase I.

4. Recommend the best technologies and prepare a recommendation for a Westinghouse Hanford Company (WHC) management board for final decision making.

In Phase I, the following was accomplished.

1. Potential vitrification systems were identified and grouped into general technology categories. A list of the technologies is presented in Section 5.0.

2. Six (of 15) technologies were selected for further consideration based on their probability of success. The selected Phase I technologies were those having the highest probability of success compared to the other alternative technologies. The six technologies selected for Phase II assessment are listed in Section 6.0.

3. Detailed criteria for evaluating the six technologies were also agreed upon during Phase $I$ and are presented in Section 7.0 .

Between Phase I and Phase II, data and engineering studies relative to the six technologies were prepared. In Phase II, the MSWG

1. Examined the data packages and engineering studies prepared between the Phase I and Phase II workshops

2. Assessed each technology against the criteria established in Phase I based on available technical information, input provided by the technical resource staff, and the expert judgement of the MSWG (a listing of the members of the MSWG and the technical resource staff, along with a brief discussion of their respective areas of expertise, is presented in Section 4.0)

3. Prepared recommendations of the technologies with the highest probabilities of success within expected TWRS Program constraints.

$$
\text { E-11. }
$$




\subsection{WORKING GROUP CONFIGURATION}

The HLW alternative melter candidate assessment was performed by the MSWG, composed of the Technical Advisory Committee (five non-Hanford Site experts) and the WHC TWRS Technical Staff (six WHC personnel). The MSWG represents a diverse cross section from academia, the commercial glass industry, and U.S. Department of Energy (DOE) HLW projects. In addition to the MSWG, a technical resource staff with broad-based combined knowledge in the field of HLW vitrification provided an independent assessment of the technologies, which was considered by the MSWG in developing it's recommendations. The meeting participants and a brief summary of their experience, specialties, and affiliations follows.

\section{TECHNICAL ADVISORY COMMITTEE}

- Frank Woolley, Technical Advisory Committee Chairman, Corning International, Incorporated

Or. Woolley is Manager of Research in the Melting Technology section of Corporate Engineering at Corning Incorporated. His group investigates the fundamental processes in glass melting and develops new industrial melting processes for Corning's domestic and international glass melting.

- L. David Pye, New York State College of Ceramics

Dr. Pye is a professor of Glass Science at the New York State College of Glass Ceramics and Director of the Institute of Glass Science and Engineering and Director of the National Science Foundation's Industry-University Center for Glass Science. He is an internationally renowned $g$ lass chemist with specific expertise in nuclear waste glasses.

- Eric Brown, British Nuclear Fuels Limited

Mr. Brown has thirteen years of lead experience in design, installation, startup, operation, and decommissioning relative to the British HLW vitrification plant in Sellafield, England. The Sellafield Plant uses the French-designed, low-frequency, inductionheated, metal-can melter system technology. Mr. Brown has specific expertise in the design, operation, and maintenance of the melter system and melter support system components.

- Joseph Gentilucci, JAG Tech Services, Incorporated

Mr. Gentilucci is a private consultant. He is retired after working sixteen years on various aspects related to the design, construction, and startup testing of the Savannah River Site's HLW Defense Waste Processing Facility. His last position was Manager of Process Engineering responsible for maintaining overall technology assurance and configuration of the process, including directing technical experimental programs required to support operations. 
- Steven M. Barnes, West Valley Nuclear Services

$\mathrm{Mr}$. Barnes has managed the integrated process system testing activities at the DOE West Valley Demonstration Project (WVDP) HLW vitrification plant in West Valley, New York. He also has specific experience in the design and development of the WVDP meiter technology and waste form qualification activities.

TANK WASTE REMEDIATION SYSTEM TECHNICAL STAFF

- Rod Powel1

Dr. Powell is the TWRS HLW Project Office Manager. His experience includes twenty-plus years in nuclear materials development.

- Gary Stegen

Mr. Stegen is a Principal Engineer in the TWRS Vitrification Development Group with twenty years of experience, including eight years of process engineering for the HWVP Project and eight years of experience in chemical process research and development.

- James Baker

Mr. Baker's last seven years of experience have been in HLW vitrification plant process design with the HWVP Project.

- Robert Watrous

$\mathrm{Mr}$. Watrous has thirty-four years of experience in reactor fuels preparation, fuels separations processing, and HLW disposal technology development, at both the Hanford and Oak Ridge DOE sites. This includes seven years of experience with the HWVP Project.

- Ronald Calmus

Mr. Calmus has four years of experience in nuclear plant materials performance engineering and plant engineering/operations, two years of research and development of nuclear materials and four years of HLW vitrification system development and testing with the HWVP Project.

- George Janicek

Mr. Janicek has thirty-plus years experience in the nuclear field, including eleven years in design and development of remote handling and facility systems and five years in HWVP operations and maintenance engineering design. 


\section{TECHNICAL RESOURCE STAFF}

- Dennis Bickford, Westinghouse Savannah River Company

Mr. Bickford has lead responsibility for identifying and developing new nuclear waste vitrification process technologies for the DOE Savannah River Site (SRS) and has specific expertise in the DWPF melter technology and DWPF alternative vitrification system technologies being considered for processing SRS HLW.

- Chris Chapman, Pacific Northwest Laboratory

Mr. Chapman has lead responsibility for melter system development for the Pacific Northwest Laboratory (PNL) and was a primary developer of the joule-heated, ceramic-lined melter technology that is the baseline HLW vitrification technology for most of the world, including the United States (WVDP/DWDP/HWVP), Japan, and Europe (excluding France and England).

- Wolfgang Grunewald, Kernforschungszentrum, Karlsruhe GmbH

Mr. Grunewald is a primary developer of the German-designed jouleheated melter systems with significant experience testing and operating these systems and broad knowledge of international HLW vitrification system development activities.

- Bruce Higley, Westinghouse Hanford Company

Mr. Higley is considered a Hanford Site cognizant engineer on cyclone-combustion melting technology and is knowledgeable on recent consideration of this type of technology for vitrification of HLW.

- Antoine Jouan, French Atomic Energy Commission (CEA Marcoule)

Mr. Jouan has lead responsibility for development of the Frenchdesigned high-frequency induction melter technology (cold-crucible melter technology) and has in-depth knowledge of the commercial HLW low-frequency induction-melter technology employed in England and France relative to system development, design, and operation.

- Gunther Roth, Kernforschungszentrum, Karlsruhe GmbH

Dr. Roth is a primary developer of the German-designed joule-heated melter systems with significant experience testing and operating these systems and broad knowledge of international HLW vitrification system development activities.

- Jeffrey Serne, Pacific Northwest Laboratory

Mr. Serne is one of the Hanford Site's foremost experts on plasma and plasma-arc melter technologies relative to design, development, testing, and operation of this technology for commercial applications. 


\subsection{TECHNOLOGIES CONSIDERED} workshop were

Candidate technologies identified and discussed during the Phase I

- Ceramic-lined, low-temperature, Joule-heated melters

- Metal-lined, stirred, low-temperature, Joule-heated melters

- Ceramic-lined, high-temperature, Joule-heated melters

- Metal-lined, high-temperature, Joule-heated melters (hot wall)

- Metal-lined, high-temperature, Joule-heated melters (cold wall)

- Conventional combustion melters

- Cyclone combustion melters

- Low-frequency induction melters

- High-frequency induction melters

- Plasma torches (entrained)

- Plasma torches (indirect heating)

- Transferred-arc plasma melters

- Arc furnaces

- Microwave melters

- Rotary kiln

- Hot isostatic pressing

- In-can melters.

Each candidate technology was assessed for probability of success in meeting the following minimum requirements: (1) produce a consistent, acceptable waste form, (2) be successfully developed within TWRS Program constraints, including Tri-Party Agreement milestone constraints, and (3) incur reasonable total program cost compared to other technologies.

Identified technologies were assessed and assigned a comparative ranking as to whether the technology had a low, moderate, or high probability of success relative to all Phase I requirements. The four technologies with a high probability of success were selected for further consideration in the Phase II assessment. In addition, two technologies with a moderate probability of success were selected for further consideration based on a determination by the MSWG that specific attributes of the technologies deserved further consideration.

\subsection{SHORT LIST TECHNOLOGIES}

The technologies selected for in-depth evaluation in the Phase II assessment were

- Ceramic-lined, low-temperature, Joule-heated melters (high probability of success)

- Metal-lined, stirred, low-temperature, Joule-heated melters (high probability of success) 
- Ceramic-lined, high-temperature, Joule-heated melters (high probability of success)

- High-frequency induction melters (high probability of success)

- Metal-lined, high-temperature, Joule-heated meiters (cold wall) (moderate probability of success)

- Low-frequency induction melters (moderate probability of success).

\subsection{EVALUATION CRITERIA AND DECISION-MAKING PROCESS}

General criteria and detailed definitions and attributes for the Phase II evaluation were developed during the Phase I workshop. The following is a summary of the Phase II criteria.

- Process a range of compositions

- Flexibility to process glass formulated for expected waste compositions within melter operating parameters

- Control product quality

- A consistent glass product with a controlled composition

- Melter system design or performance characteristics that improve or reduce ability to produce a consistent, predictable, product with the desired composition and properties

- Develop technology on schedule

- Basis to develop technology to the point that key technical issues are resolved within schedule constraints

- Features of technology carrying a high degree of risk

- Options to reduce technical risk, within schedule, to the point that the technology can be considered a viable HLW plant melter system for incorporation into detailed design

- Integrate with process and facility

- Ability to integrate easily with upstream and downstream processing steps as well as facility constraints

- Ability to meet requirements placed on the balance of $p l a n t$ and support systems (e.g., facility size, maintenance systems, safety mitigation systems, offgas, canister handling, waste handling and disposal, and secondary waste treatment systems) by the proposed HLW vitrification technology and unique process flowsheet features 
- Ease of and ability to control and maintain the process and facility

- Design features related to remote operation and maintenance (such as the ability to drain the melter if required), the ability to replace parts, and the potential for performing these operations remotely

- Operational simplicity, compactness of design, passive features, and the number of moving or consumable parts

- Suitability of the melter system for operation and maintenance in a radiologically controlled environment

- Expected operating lives for melter and radioactive, contaminated support equipment and ease of disposal

- Size and quantity of contaminated equipment and materials requiring disposal

- Minimize total cost

- Provide the required product at a minimum TWRS HLW Disposal Program cost

- Design features and requirements that significantly affect iife-cycle costs, such as development costs, melter system disposal, secondary feed stream and equipment disposal, consumable parts, energy and utilities requirements, glass former materials or feed additives, and quantity of glass produced (glass product disposal costs)

- Minimize safety and environmental risk

- Ability of melter system to operate safely in a remote environment

- Probability and consequences of unsafe or costly upset event

- Consider other risks and limitations

- Risk to schedule based on resolving institutional barriers

- Unusual and/or special considerations.

Each technology was evaluated against the criteria to establish a comparative ranking. The decision process included the following steps.

- Prepare Phase II assessment information.

Detailed data packages and engineering balance-of-plant studies were prepared for each technology included in the Phase II assessment. The portion of the data package specific to the vitrification system (calciner/dryer, melter, glass holding tanks, and ancillary melter equipment) was prepared by PNL. This portion of the package was compiled from open literature specific to the general technology 
group and from requested nonproprietary vendor information. An effort was made to obtain vendor or developer information related to specific discriminating features within each technology group. The PNL section of each data package was reviewed for adequacy by WHC TWRS technical staff and independently reviewed by cognizant technical staff from the DOE SRS. The vitrification system data packages will be issued as a PNL TWRS report.

Engineering studies were performed by Fluor Daniels Incorporated to assess the impact of the different vitrification system technologies on balance-of-plant equipment and the plant facility. The balanceof-plant studies focused on expected key cost discriminators: melter system equipment disposal, facility size (e.g., melter cell, transport corridors, and crane requirements), and feed preparation and offgas systems. The study found that the effect of melter technology selection on initial plant cost was relatively small compared to total projected facility capital and operating costs. The study also found that the cost of providing facility flexibility to allow use of multiple melter types is relatively small.

Partially completed data packages were submitted to the MSWG and technical resource staff prior to the Phase II workshop. The remaining data packages were provided during the workshop and reviewed during the workshop proceedings, as required.

- Identify and discuss each technology's key strengths and weaknesses relative to each criterion.

- Score the technologies against specific criteria.

The criteria were numerically scored by the MSWG and technical staff. Individual attributes were al so scored when required for clarity and discussion. Individual scoring results for each technology were used to promote further detailed discussion and to provide the basis for a final numerical consensus score for each technology group against the evaluation criteria. The consensus scores indicated the MSWG's (and separately, the technical resource staff's) expert opinion of each melter technology's relative performance according to the criteria.

- Perform an overall assessment of all technologies to provide a recommendation that can be used to establish a technically sound, cost-effective, success-oriented melter system development plan.

The overall assessment was performed by the TAC. The scoring results were used to identify significant differentiators between the technologies. It was apparent that two of the six Phase II technologies had a much lower probability of success based on the scoring results. These two technologies scored lower than the other technologies for the bulk of evaluation criteria. These were el iminated from further consideration.

From the scoring it was apparent that key discriminators between the remaining four technologies were the development status of the technologies and the operating temperature regime, which influences waste processing flexibility and total volume of glass product 
requiring disposal. The other four technologies were then regrouped into two primary technologies, which form the basis of the MSWG recommendation. The two regrouped technologies are: Joule-heated, electroded melter systems and induction-heated cold-wall melter systems. This regrouping was deemed appropriate by the TAC to provide a well-balanced melter system development test direction.

- Discuss the TAC recommendation with the Hanford members of the MSWG to determine if there were any key disagreements.

The TAC recommendations were adopted by the entire MSWG with minor editorial modifications.

\subsection{APPLICATION OF RESULTS}

Implementation of this recommendation will require preparation of shortand long-term development strategies to form the basis to prepare work scope and resource change packages. The short-term (FY-1995) technical direction of development activities will focus on small-scale laboratory and melter system feasibility. testing, including materials testing, and will require some revisions to the FY-1995 planning baseline. The identified changes to FY 1995 work scope and resources allocation will be prepared as Change Requests by mid-November 1995. In the interim, we see no need to change the direction of PNL activities on high-temperature electrode materials testing and small-scale joule-heated, ceramic-lined melter testing. We also intend to proceed with small-scale proof-of-principle test with the high-frequency induction melter technology (cold crucible melter). 
This page intentionally left blank. 
WHC-EP-0847

APPENDIX $F$

CONCURRENCE WITH HIGH-LEVEL WASTE MELTER

ALTERNATIVES ASSESSMENT DECISION

\section{F-1}


WHC-EP-0847

This page intentionally left blank.

F-2 


\section{WHC-EP-0847 \\ Department of Energy \\ Richland Operations Otfice \\ P.O. $80 \times 550$ \\ Ricnland. Washington 99352}

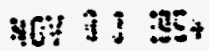

94-RTI-030

President

Westinghouse Hanford Company

Richland, Washington

Dear Sir:

CONCURRENCE WITH HIGH-LEVEL WASTE (HLW) MELTER ALTERNATIVES ASSESSMENT OECISION

Reference: WHC Letter 9456834, J. O. Honeyman, WHC, to L. Erickson, RL, "High Level Waste Melter Alternatives Assessment Decision," dated October 18, 1994.

In response to the reference above, DOE concurs in the Hestinghouse Hanford Company decision to implement the recommendation from the HLW Melter

Alternatives Assessment. WHC is requested to review the Multi-Year Work Plan relative to this decision and formally make the necessary adjustments in accordance with established change control procedures.

If you have questions regarding this matter, please contact Jon Peschong, of my staff, on 376-9327.

RTI:JCP

CC: R. W. Powell, WHC

J. O. Honeyman, WHC
Sincerely,<smiles>[CH][CH]</smiles>

Keif Erhckson, Director

Tank Waste Retrieval, Treatment, and Immobilization Division 
WHC-EP-0847

This page intentionally left blank.

F-4 


\section{DISTRIBUTION}

\section{Number of Copies}

OFFSITE

1

U.S. Department of Energy-Headquarters 12800 Middlebrook Rd. Germantown, Maryland 20874

J. Hennessey

$E M-361$

ONSITE

10

U.S. Department of Energy, Richland Operations office

N. R. Brown

$57-53$

S. T. Burnum

S7-53

D. D. Button

$57-53$

R. Carreon

L. Erickson

S7-53

J. C. Peschong (3)

$57-53$

Public Reading Room

S7-53

Hanford Technical Library

H2-53

P8-55

Pacific Northwest Laboratory

J. M. Creer (3)

K9-80

Westinghouse Hanford Company

R. B. Calmus (4)

H5-27

D. K. Carter

G3-20

L. F. Ermold

J. S. Garfield

S7-84

R. L. Gibby (3)

H5- 49

J. 0. Honeyman

H5-27

D. A. Kummer

S7-81

S. R. Nelson

R. W. Powell (3)

B3-70

G6-14

P. S. Schaus

G3-20

G. E. Stegen

G3-20

J. A. Swenson

H5-27

D. J. Washenfelder

H5-49

R. D. Wojtasek

H5-27

Central Files

S7-84

OSTI (2)

L8-04

L8-07 